\title{
Fruit bromelain derived peptides destabilize growth of amyloidal fibrils
}

\section{Sromona Das ${ }^{1,2}$, Sangita Dutta ${ }^{2}$, Ramesh K Paidi ${ }^{3}$, Subhas C Biswas ${ }^{3}$, Umesh \\ $\mathrm{C} \mathrm{Halder}^{1 *}$ and Debasish Bhattacharyya ${ }^{2,4 *}$}

${ }^{1}$ Department of Chemistry, Jadavpur University, 188, Raja S.C. Mallick Road, Jadavpur, Kolkata -700 032, India

${ }^{2}$ Division of Structural Biology and Bioinformatics

${ }^{3}$ Division of Cell Biology and Physiology

CSIR-Indian Institute of Chemical Biology, 4, Raja S.C. Mallick Road, Jadavpur, Kolkata -700 032, India

${ }^{4}$ National Institute of Pharmaceutical Education and Research, Kolkata, India.

*Corresponding author

Type of Manuscript:

Running title:

Key words:
Email: dbhattacharyya1957@gmail.com

Phone: + 919433560004

Present address: Adjunct Faculty

National Institute of Pharmaceutical Education and Research, Kolkata, India.

Email: uchalder@chemistry.jdvu.ac.in, uhalder2002@yahoo.com

Phone: + 919433487622

Regular research article

Destabilising amyloidal fibrils by bromelain petides

Aggregation; amyloid-beta; amyloidal fibrils; digested bromelain peptides; destabilisation. 


\section{ABSTRACT}

$35 \quad \beta$-Amyloid deposition as fibrillar plaques in brain is the primary cause of Alzheimer's disease.

36 We report potency of cysteine protease 'fruit bromelain' from pineapple in destabilising $A \beta$

37 fibrils. Bromelain peptide pool $(\mathrm{Mw}<500 \mathrm{Da})$ obtained mimicking human alimentary tract

38 digestion inhibited fibrillation from monomeric and oligomeric states of $\mathrm{A} \beta$ and irreversibly

39 dissociated preformed fibrils into small oligomers of varied sizes. Time kinetics was followed by

40 Thioflavin-T assay and microscopic imaging. Synthetic bromelain peptides corresponding to $A \beta$

41 sticky region found using ClustalW analysis revealed specificity of peptides in destabilisation of

42 amyloidal structures. Spectra of different molecular states of A $\beta$ obtained from application of 8-

43 anilino-1-naphthalenesulfonic acid, circular dichroism and Fourier-Transformed Infrared

44 spectroscopy collectively indicated interaction dependent structural change. Probable mechanism

45 for fibril dissociation was thus predicted. Peptides relieved A $\beta$ cytotoxicity on pheochromcytoma

46 cells and dissociated plaques in $\mathrm{AD}$-type rats prepared by bilateral intracerebroventricular

47 administration of $A \beta$ in rat brain cortex. Pineapple being a phytoceutical, its efficiency to

48 disaggregate amyloid bodies warrant further investigation.

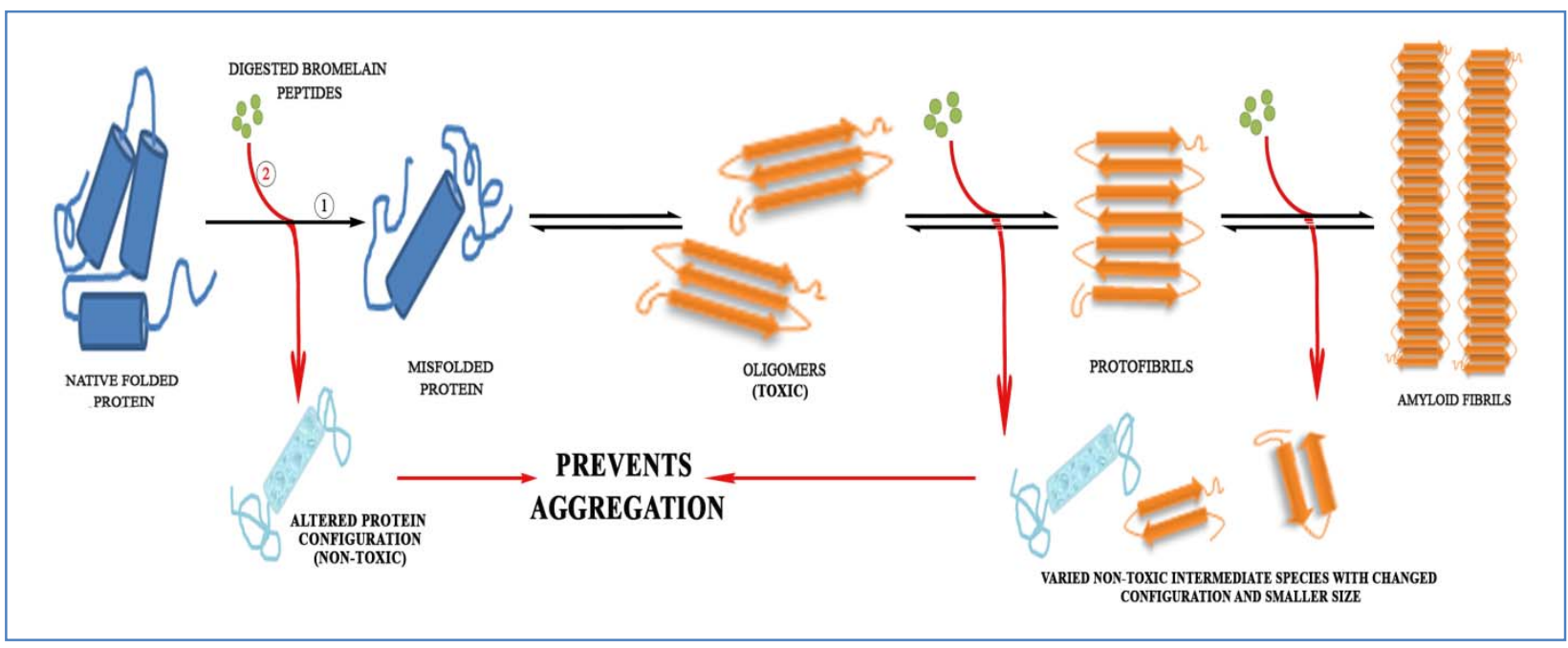


The occurrence of dementia has increased to one individual every 3 seconds, with 50 million

53 affected people in 2018 and according to World Alzheimer's Report, this will almost double

54 every 20 years, reaching 82 million in 2030 and 131.5 million in 2050. Alzheimer's disease

55 (AD), the most widely studied and common form of dementia, accounts to 60-80\% cases and is

56 the sixth leading cause of death in USA [1]. Casual factors for AD though known for a very

57 small $1-2 \%$ of the total population, it is still unknown for majority of cases. Though several

58 factors, such as the ApoE4 genotype and polymorphism in several genetic loci have been

59 identified alongside type 2 diabetes, brain injury, stroke, diet and other environmental factors, aging stands as the first risk factor.

$\mathrm{AD}$ is an age-related progressive, neurodegenerative disorder characterized by gradual memory loss, cognitive abilities, characteristic neuropathological amyloid plaque depositions, formation of neurofibrillary tangles and severe neuronal loss in diverse regions of brain cortex [2]. A characteristic hallmark includes irreversible brain degeneration in elderly people. The amyloid deposits and senile plaques mainly contain insoluble, aggregated proteins, the main constituent being $\beta$-amyloid (A $\beta 42)$, derived from a $170 \mathrm{kDa}$ cellular amyloid precursor protein (APP) $[3,4]$. Several lines of evidence suggest a pathogenic role for $A \beta$ assembly in progression of $\mathrm{AD}$, and increasing evidences point specifically towards soluble protofibrillar intermediates as a pathogenic species [5]. Thus, there is considerable interest in studying the structures and assembly mechanisms of proteins into amyloid structures and their precursors. Consequently, though there is more than one stage that can be targeted, preventing aggregation is the primary therapeutic target.

Several pioneering work has led to the possibility of generating small and soluble oligomeric forms of $\mathrm{A} \beta$ in vitro [6] and these oligomers have proved detrimental on binding to synaptic neurons [7]. AD, a multifaceted disease involves multiple cellular changes, including synaptic and neuronal loss, activation of microglia and astrocytes, mitochondrial damage, and tau phosphorylation. Thus, various therapeutic strategies have been developed based on these modifications but no certain cure is available till date and is also nevertheless dose-dependent. Further, there are no available biomarkers that can relate symptoms of AD in individuals. 
Physical exercise and healthy diets, few of the best remedies targeted towards good health decelerates growth of AD in elderly people, thereby aiding memory and learning skills in early $\mathrm{AD}$ patients and individuals having low cognitive impairment [8]. Natural products, a major component of healthy diets have multiple health benefits, including anti-inflammatory, antioxidant, anti-arthritis, neuroprotective and memory cognitive functions [9]. Many well known natural products and herbs currently include green tea, $\beta$ carotene, vitamins $\mathrm{E}$ and $\mathrm{C}$, rosemary, curcumin, ginseng, sage and many others $[8,9]$. Concentrating specifically on natural products and targeting small molecules, we studied protective effects of pineapple extract derived enzyme, bromelain against $\mathrm{A} \beta$ induced toxicities in $\mathrm{AD}$ pathogenesis.

Bromelain, the cysteine protease from pineapple has broad specificity. It hydrolyzes diverse substrates like native and partly denatured collagen, elastin, casein, fibrin, hemoglobin etc. It offers a wide range of therapeutic efficacies and due to its efficiency after oral administration, safety and lack of undesired side effects; bromelain is being increasingly accepted as a phytotherapeutical drug [10]. In this perspective, investigation was carried out to verify whether bromelain derived peptides could destabilize preformed $A \beta$ aggregates. As a first step towards understanding interactions between fruit bromelain derived peptide pool and $A \beta$ aggregate, we described effect of bromelain on preformed $A \beta$ aggregates in vitro. Although structural information available for $A \beta$ complexes is sparse, this analysis is likely to reveal features relevant to $A \beta$ binding and generate initial hypotheses highlighting effect of peptide pool on A $\beta$ aggregate. Earlier reports show that inactive and autodigested fruit bromelain act as a kinetic/nucleation inhibitor of amyloid formation in human insulin [11].

101

In this study, amyloid aggregates were reconstituted in vitro in a controllable manner and

102

103

104

105

106

107

108

109

110 anti-amyloidogenic effect of bromelain peptide as an early quick battery test was performed before cellular and animal studies. The work described that fruit bromelain derived peptides, obtained from extensive digestion by various proteases found in human gastrointestinal tract, have an anti-aggregation property and can permeate the blood brain barrier (BBB) with respect to its small size. Further, three methods have been used to understand the effect in preventing formation of aggregates from (i) monomers, (ii) oligomers and also (iii) disaggregation of preformed $A \beta$ fibrils. The self-assembling evaluation of $A \beta$ in vitro will provide an opportunity to screen molecules for anti-amyloidogenic property of therapeutic significance for new AD drug discovery. 
111

112

113

114

115

116

117

118

119

120

121

122

123

124

125

126

127

128

129

130

131

132

133

134

135

136

137

138

139

140

\section{EXPERIMENTAL SECTION}

\section{Materials}

Fine chemicals were procured as follows: Thioflavin T (Th T) from Acros Organics, Belgium; 8anilino-1-naphthalene sulfonic acid (ANS), 1,1,1,3,3,3-Hexafluoroisopropanol (HFIP) and Paraformaldehyde (PFA) from Sigma-Aldrich, St. Louis, Missouri, USA; Dimethyl sulfoxide (DMSO) from HiMedia Laboratories, Mumbai, India; trypsin (3x crystallized, bovine pancreas), carboxypeptidase (bovine pancreas, type II - PMSF treated aqueous suspension), $\alpha$-chymotrypsin (hog pancreas), elastase (porcine pancreas) and pepsin from SRL, Mumbai, India; acetic acid, formic acid, Acetonitrile (ACN) and Trifluoroacetic acid (TFA) from Merck, Germany; urethane from AMRESCO, Texas, USA; uranyl acetate from BDH Corporation, Mumbai, India; copper grids (300-mesh size) and mica sheets (size $20620 \mathrm{MM}, 0.27$ - $0.33 \mathrm{~mm}$ thickness) from Electron Microscopy Sciences, Pennsylvania, USA; MTT from Molecular Probes, Invitrogen, USA; Dulbecco's Modified Eagle's Medium (DMEM), penicillin-streptomycin, trypsin-EDTA and Fetal Bovine Serum (FBS) from Gibco, Maryland, USA. HPLC-purified peptides A $\beta 40 / 42$ were procured from American Peptide, Sunnyvale, CA, USA. Physical and chemical homogeneity of monomeric A $\beta$ peptide was verified by mass spectrometric analysis where other than trace amount of dimer, trimer and tetramer of the peptide, no other impurities could be detected.

\section{Preparation of A $\beta 40 / 42$ oligomers and fibrils}

A $\beta 40 / 42$ oligomers and fibrils were prepared following Barghorn et al., 2005 [12]. Briefly, lyophilized A $\beta$ peptide was reconstituted in $100 \%$ HFIP to a concentration of $1 \mathrm{mM}$. HFIP was removed by evaporation in a Speed Vac and then resuspended to $5 \mathrm{mM}$ in anhydrous DMSO. This stock served as monomeric $\mathrm{A} \beta$ and was stored at $-80^{\circ} \mathrm{C}$. The stock was diluted to $400 \mu \mathrm{M}$ with Phosphate Buffer Saline (PBS) containing $0.2 \%$ SDS and incubated at $37^{\circ} \mathrm{C}$ to form oligomeric intermediates. A further dilution with PBS to $100 \mu \mathrm{M}$ and incubation at $37^{\circ} \mathrm{C}$ for 96 $\mathrm{hr}-7$ day formed amyloid structures having increased level of crosslinks.

\section{Preparation of fruit bromelain}

Fresh ripe pineapple (100 g) was cut into small portions, smashed by a household grinder and centrifuged at $10,000 \mathrm{rpm}$ for $15 \mathrm{~min}$ at $4{ }^{\circ} \mathrm{C}$ to separate fibrous materials from edible portion.

The lyophilized supernatant was reconstituted in $10 \mathrm{mM}$ Na-phosphate, $\mathrm{pH}$ 7.5, and centrifuged as stated. The clear supernatant $(2 \mathrm{ml})$ was passed through Sephadex G-50 column $(1.5 \times 90 \mathrm{~cm})$ 
141 pre-equilibrated with the same buffer at $25^{\circ} \mathrm{C}$. Flow rate was maintained at $12 \mathrm{ml} / \mathrm{hr}$. Fractions

142 collected were followed at $280 \mathrm{~nm}$ and assayed for proteolytic activity using azocasein as

143 substrate [13]. Proteolytic activity of bromelain was confined to the first peak fraction while the

144 second contained pigments, salts and small peptides. Active fractions were pooled and dialyzed

145 against $1 \mathrm{mM}$ Na-phosphate, $\mathrm{pH} 7.5$ and lyophilized. All spectrophotometric measurements were

146 taken in Specord 200 spectrophotometer (Analytik Jena, Germany). Bromelain concentration

147 was measured using $\square^{1 \%}{ }_{280 \mathrm{~nm}}=2.01$ [14]. This preparation is a mixture of bromelain isoforms

148 and minor amount of other cysteine proteases of similar molecular weight [15].

149

150

151

152

153

154

155

\section{Peptides derived from fruit bromelain under conditions of human digestive system}

The fruit bromelain protein pool $(10 \mathrm{mg})$ was dissolved in $2 \mathrm{ml}$ of $5 \% \mathrm{HCOOH}$ to obtain an acidic solution ( $\mathrm{pH} 2.0$ ) followed by addition of Pepsin (2 mg, 1:50 wt/wt) and incubation at $37^{\circ} \mathrm{C}$ for $3-4 \mathrm{hr}$. Thereafter, $\mathrm{NH}_{4} \mathrm{HCO}_{3}$ was added to increase $\mathrm{pH}$ of the solution to 7.5. Trypsin and chymotrypsin (2 mg each, 1:50 wt/wt) were sequentially added along with trace amount of elastase and carboxypeptidase for further digestion at $37^{\circ} \mathrm{C}$ for $7-8 \mathrm{hr}$. Incubation conditions were maintained mimicking human gastrointestinal tract digestion.

\section{Separation of bromelain peptides by Sep-Pak C18 Cartridges}

Fruit Bromelain derived peptide pool was separated from undigested protein part by using Waters C18 Sep-Pak Cartridges. Prior to use, cartridges were washed with $10 \mathrm{ml}$ acetonitrile and equilibrated with water containing $0.1 \%$ TFA. After sample loading, unabsorbed proteins and large peptides were eluted and cartridge washed with water containing 1\% TFA. Peptide pool was eluted with $2 \mathrm{ml} \mathrm{50 \%} \mathrm{acetonitrile} \mathrm{containing} \mathrm{0.1 \%} \mathrm{TFA.} \mathrm{MS} \mathrm{analysis} \mathrm{revealed} \mathrm{presence} \mathrm{of}$ peptides ranging from $200 \mathrm{Da}$ to $>1 \mathrm{kDa}$. For further fractionation according to size, the pool (2 ml) was applied to Sephadex G-10 column ( $85 \mathrm{ml}$, fractionation range <700 Da) fitted with Biologic duo flow instrument (Bio-Rad) at a flow rate of $6 \mathrm{ml} / \mathrm{hr}$. Fractions eluted were continuously monitored at 220/280 $\mathrm{nm}$ in a UV visible spectrophotometer, collected according to peak positions and further characterized by MS analysis.

\section{Fluorometric quantification of amyloid aggregates}

Th-T assay was employed to follow aggregation kinetics of $\mathrm{A} \beta$. Th-T, a fluorescent dye interacts with $\beta$-sheet rich fibrils leading to characteristic increase in fluorescence intensity in the vicinity 
of $480 \mathrm{~nm}$, relative to unbound Th-T (ex: $450 \mathrm{~nm}$; em: 460-600 nm). $\lambda_{\max }$ emission intensity varies from 480 to $487 \mathrm{~nm}$ [16]. A Hitachi F4500 fluorescence spectrometer attached to a circulating water bath at $25 \square$ was used (ex/em slit widths $5 / 5 \mathrm{~nm}$ ). A stock solution of Th-T (250 $\mu \mathrm{M}$ in water) was made using $\square_{412 \mathrm{~nm}}=35,000 \mathrm{M}^{-1} \mathrm{~cm}^{-1}$ and aliquots of $10 \mu \mathrm{l}$ were transferred to the reaction mixture before fluorescence measurements were recorded. The reaction mixture consisted of $10 \mathrm{mM}$ Na phosphate, $\mathrm{pH} 7.5$ and 1-10 mM peptide solution in a final volume of 1 ml. Blank correction was done for all ( $\mathrm{n}=5$, with replicates of 5 in each set).

\section{Determination of Protein and peptide concentration}

While bromelain peptide concentration was determined optically using molar extinction coefficient of peptide bond at $\square_{214 \mathrm{~nm}}=923 \mathrm{M}^{-1} \mathrm{~cm}^{-1}$ in presence of acetonitrile and formic acid [17], concentration of $A \beta$ was evaluated using $\square_{276 \mathrm{~nm}}=1450 \mathrm{M}^{-1} \mathrm{~cm}^{-1}[\mathbf{1 8}]$.

\section{Mass spectrometry analysis}

Molecular mass of peptide pool was determined using a Q-Tof Mass Spectrometer (Waters Corporation, USA). The sample was desalted using Zip-Tip $\mu-\mathrm{C}_{18}$ (Millipore, Billerica, MA, US). Matrix bound samples were eluted in $50 \%$ acetonitrile in water containing $0.01 \%$ formic acid. Samples were further analyzed under positive mode of ESI at desolvation temperatures of $100-125^{\circ} \mathrm{C}$. Argon as a collision gas at $2 \mathrm{~kg} / \mathrm{cm}^{2}$ having collision energy of $10 \mathrm{eV}$ was applied. Micro channel plate detectors were used.

\section{Dynamic Light Scattering (DLS)}

DLS monitors change in particle size and distribution, and calculates average hydrodynamic radius during protein/peptide aggregation. DLS measurements of different $A \beta$ species in presence and absence of bromelain derived peptides were taken using a back-scatter apparatus (Malvern Nano ZS, Malvern) having a constant scattering angle of $90^{\circ}$, at $25 \pm 1^{\circ} \mathrm{C}$ [19]. Samples were diluted to a final concentration of $0.1 \mathrm{mg} / \mathrm{ml}$ in a total volume of $1 \mathrm{ml}(\mathrm{n}=5$, with replicates of 5 in each set).

\section{Transmission Electron Microscope (TEM)}

Samples were placed on a 300-mesh copper grid covered by carbon-coated film and incubated for $10 \mathrm{~min}$ at $25^{\circ} \mathrm{C}$. The excess fluid was removed and grids were negatively stained for $30 \mathrm{sec}$ with $10 \mu \mathrm{L}$ of $1 \%$ uranyl acetate solution. Excess stain was removed by repeated washing with 
Milli-Q water and samples were visualized in a TECNAI G2 TEM (Thermo Fischer Scientific, USA) operating at $120 \mathrm{kV}$ accelerating voltage and 1,15,000x. To estimate widths of individual fibres, digital electron micrographs were analyzed by MCID Elite (Micro Computing Imaging Device 7.0, revision 1.0, Imaging Research, Inc.).

\section{Atomic Force Microscopy (AFM) Imaging}

Protein samples (10 $\mu \mathrm{l}, 200 \mathrm{ng} / \mathrm{ml})$ were deposited onto freshly cleaved mica sheets and air-dried for $20 \mathrm{~min}$. Sometimes the sample was gently washed with $0.5 \mathrm{ml}$ Milli-Q water to remove molecules that were not firmly attached to the mica and then air-dried as above. Acoustic AC (AAC) mode AFM was performed using a Pico plus 5500 AFM (Agilent Technologies, USA) with a piezoscanner maximum range of $9 \mu \mathrm{m}$. The cantilever resonance frequency was $150-300$ $\mathrm{kHz}$.

Cells were seeded on glass cover slips maintaining a density of $10^{6}$ cells/well in a 6-well plate and treated with media containing $5 \mu \mathrm{M}$ of $\mathrm{A} \beta 40 / 42$ at $0 \mathrm{hr}$ with or without $5 \mu \mathrm{M}$ of synthetic peptides, after preincubation for $24 \mathrm{hr}$. The same media volume was added to control cultures. Cells were incubated for an additional period of $48 \mathrm{hr}$ at $37^{\circ} \mathrm{C}$ and allowed to reach 70 $80 \%$ confluency. Cover slips with adherent cells were then washed with 1X PBS to completely remove media, followed by fixation with $1 \% \mathrm{PFA}$ for $1 \mathrm{hr}$ at $4^{\circ} \mathrm{C}$. Prior to imaging PFA was rinsed well with 1X PBS and finally with double-distilled water to prevent deposition of any excess buffer molecule. Imaging was done in dry mode using 100 micron scanner. Cantilevers of $450 \mu \mathrm{m}$ length with a nominal spring force constant of $0.2 \mathrm{~N} / \mathrm{m}$ were used. Resonance frequency was set at $13 \mathrm{kHz}$. Individual plots shown for surface topography of various samples are representative views of morphologies observed for multiple areas of the samples.

In both sets, images (512 by 512 pixels) were processed using Pico scan software (Molecular Imaging Corporation, San Diego, CA).

\section{Disaggregation of amyloidal protein by bromelain derived peptides}

The following experiments were designed to evaluate anti amyloidogenic property of protease digested small peptide pool of fruit bromelain using three-phase study protocol [20]: (i) freshly prepared A $\beta 40$ was co-incubated with digested peptide $(7 \mu \mathrm{M})$ for $96 \mathrm{hr}$. Aliquots were withdrawn at $0,6,20,72$ and $96 \mathrm{hr}$; (ii) Oligomers of $\mathrm{A} \beta 40$ were formed from freshly prepared monomeric peptide upon incubation for $20 \mathrm{hr}$. Thereafter, aggregation was followed in presence 
229

230

231

232

233

234

235

236

237

238

239

240

241

242

243

244

245

246

247

248

249

250

251

252

253

254

255

256

257

and absence of bromelain derived peptides up to $96 \mathrm{hr}$. Aliquots were taken at 20, 36, 48, 72 and $96 \mathrm{hr}$ post initiation of oligomerization and, (iii) Matured $\mathrm{A} \beta 40 / 42$ fibrils were formed after incubation of monomeric peptide for $96 \mathrm{hr}$. Thereafter, bromelain derived peptides were added and disaggregation of fibrils was monitored for $48 \mathrm{hr}$. In all sets, samples were analyzed by Th T assay and TEM or AFM images. Peptide solutions without aggregates served as control for fluorescence measurements $(n=5$, with replicates of 5 in each set).

\section{Conformational studies}

Interactions with ANS- ANS, an extrinsic fluorescent probe interacts nonspecifically with surface hydrophobic patches of proteins resulting in significant increase of quantum yield [21]. Emission intensity of $\mathrm{A} \beta(100 \mu \mathrm{M})$ was followed in presence of $0-500 \mathrm{mM}$ of ANS in $10 \mathrm{mM}$ Na-phosphate, pH 7.5 (ex: $380 \mathrm{~nm}$; em: 400-550 nm; em $\max : 470 \mathrm{~nm}$ ). Spectral corrections with ANS as control were done for all sets.

Fourier-Transform Infrared (FT-IR) Spectroscopy- FT-IR spectra were recorded in a Tensor 27 FT spectrometer equipped with a liquid $\mathrm{N}_{2}$-cooled mercury cadmium telluride detector. For each spectrum, water vapor used as blank was subtracted for baseline correction. Spectra were obtained using Bruker, Opus Software and scans were taken between 1,590 and 1,710 $\mathrm{cm}^{-1}$ and normalized to unity.

Circular Dichroism (CD) spectroscopy - CD spectra of $\mathrm{A} \beta(30 \mathrm{ng} / \mathrm{ml})$ were analysed using a Jasco J-815 spectropolarimeter (JASCO International, Japan). A cell having $0.1 \mathrm{~mm}$ optical path length and a bandwidth of $1 \mathrm{~nm}$ was used. Solvent spectra were subtracted from the measured spectra in each experimental set. All spectra were recorded in the far UV range of $195-250 \mathrm{~nm}$ at $25^{\circ} \mathrm{C}$ considering an average of ten scans. Spectral analysis was done with Origin Lab 8.0 software.

For all sets $n=5$, with replicates of 5 in each set were maintained.

\section{Ex-vivo studies}

Cell culture- PC12 cells were purchased from American Tissue Type Collection (ATCC), Virginia, USA. Cells were cultured in DMEM containing 10\% FBS and 1X penicillin and streptomycin mixture at $37^{\circ} \mathrm{C}$ in a humidified incubator having $5 \% \mathrm{CO}_{2}$ environment. Cells were seeded and allowed to reach $80-85 \%$ confluency before performing experiments. Five 
258 259

experimental sets were maintained: (1) untreated cells; (2) cells incubated with A $\beta$ peptide (10 $\mu \mathrm{M}$ final concentration) for $24 \mathrm{hr}$; (3) cells treated with bromelain peptide (25 $\mu \mathrm{M}$ final concentration) for $48 \mathrm{hr}$; (4) cells treated with $\mathrm{A} \beta$ for $24 \mathrm{hr}$ followed by bromelain for $48 \mathrm{hr}$ and (5) cells co-incubated with $\mathrm{A} \beta$ and bromelain for $48 \mathrm{hr}$. Around $10^{5}$ cells/100 $\mu 1$ of medium/well were maintained in a 96 well polystyrene plate. Cell viability was quantified for all sets using 3(4,5-dimethylthiazol-2-yl)-2,5-diphenyltetrazolium bromide (MTT) assay after the incubation period.

Cell viability test (MTT assay) - Mitochondrial respiration, an indicator of cell viability, was assessed in experimental sets $(n=4)$, using the mitochondrial dependent reduction of MTT to formazan [22]. MTT (10 $\mu \mathrm{l}$ from a stock of $5 \mathrm{mg} / \mathrm{ml}$ in PBS was added to each well and incubated for $4 \mathrm{hr}$ at $37^{\circ} \mathrm{C}$. The medium was then aspirated and replaced by $100 \mu \mathrm{l}$ of DMSO, following which plates were agitated at $25^{\circ} \mathrm{C}$ for $10 \mathrm{~min}$ and absorbance recorded at $590 \mathrm{~nm}$ by a multi well plate reader (Biotek-Epoch; Biotech Instruments, Winooski, VT, USA). The average absorbance value of replicate wells was considered for each set. In these experiments, cells without test samples but MTT served as positive control (blank) while cells treated with hydrogen peroxide $(10 \mu \mathrm{l})$ served as negative control.

\section{In vivo studies}

Experimental Animals- Adult male Sprague-Dawley rats weighing 280 - 330 g were procured from the random bred colony of the animal care facility of the institute (IICB) and were maintained following good husbandry conditions at standard temperature $\left(24 \pm 4^{\circ} \mathrm{C}\right)$, humidity $(60 \pm 5 \%)$ and $12 \mathrm{hr}$ light-dark diurnal cycles. They were provided with food and water ad libitum. All animal experiments were carried out as per guidelines of Institutional Animal Ethics Committee for the Purpose of Control and Supervision of Experimentation on Animals (CPCSEA), under the Division of Animal Welfare of the Ministry of Environments, Forests \& Climate Change, Government of India.

Brain Stereotaxic Surgery- Rats were anesthetized intraperitoneally with pentobarbital (50 mg/kg i.p.; Thiosol, Neon Laboratories Limited, Mumbai, India). Animals were fixed in a stereotaxic apparatus (Stoelting, MO, USA) according to Paxinos and Watson (1998) with the incision bar kept $3.5 \mathrm{~mm}$ below the interaural line and their body temperature maintained at $37^{\circ} \mathrm{C}[23]$. We 
287

288

289

290

291

292

293

294

295

296

297

298

299

300

301

302

303

304

305

306

307

308

309

310

311

312

313

314

315

316

initially compared various doses of both $A \beta$ and bromelain to analyse the dose dependency of bilateral intracerebroventricular (ICV) infusion of both in our hands, and thereby optimize the dose $(\mathrm{A} \beta, 6 \mu \mathrm{M} /$ rat and bromelain, $20 \mu \mathrm{M} /$ rat) for developing animal model in our laboratory. The stereotaxic coordinates used were: Lateral $=0.12 \mathrm{~cm}$, Anterio-posterior $=-0.90 \mathrm{~cm}$ and Dorsoventral $=0.34 \mathrm{~cm}$, with reference to Bregma point following the Rat Brain Atlas of Paxinos and Watson [24]. In the control group, artificial Cerebrospinal fluid (aCSF) (147 mM $\mathrm{NaCl} ; 2.9 \mathrm{mM} \mathrm{KCl} ; 1.6 \mathrm{mM} \mathrm{MgCl} 2 ; 1.7 \mathrm{mM} \mathrm{CaCl} 2$ and $2.2 \mathrm{mM}$ dextrose) was infused ICV (3 $\mu \mathrm{L}$ into each side). All infusions were done bilaterally with each hemisphere at a time in a total volume of $12 \mu \mathrm{L}(6 \mu \mathrm{L} /$ side $)$ at a flow rate of $0.5 \mu \mathrm{L} / \mathrm{min}$. The infusion probe was left in position for an additional five minutes after each drug delivery for proper diffusion of drug into the ventricles. Proper postoperative care, including hand-held feeding was provided until animals recovered completely.

Experimental sets comprised of animals treated with: (1) $A \beta$, (2) bromelain, (3) $A \beta$ followed by bromelain after 21 days and (4) A $\beta$ +bromelain simultaneously. On the respective day of sacrifice (21 days post infusion of $A \beta$ and 14 days post infusion of bromelain), the rats were anaesthetized with urethane and transcardially perfused with 1X PBS (pH 7.2) followed by $4 \%$ paraformaldehyde in PBS for 5 min each,. The brains were removed under perfusion conditions and fixed overnight in PBS containing 4\% paraformaldehyde and subsequently transferred into $30 \%$ sucrose in PBS after $48 \mathrm{hr}$ to allow cryoprotection.

\section{Histology}

Brain samples stored in PBS-30\% sucrose solution was investigated later by tissue histopathology using hematoxylin-eosin staining. Slides were prepared following usual H\&E staining post parafilm block preparation and tissue sectioning using manual microtome machine (Leica RM2235 Manual Rotary Microtome for Routine Sectioning). Histological analysis of wound tissue samples was carried out with an Olympus SZX 10.

\section{Statistical analyses}

All experimental results have been reported as mean \pm SEM. Student's t-test was performed in each case to evaluate significant difference between means and has been represented as p values. Number of replicates performed for each experiment has been mentioned in the respective sections. 


\section{RESULTS}

\section{Destabilization of $\mathbf{A} \boldsymbol{\beta}$ amyloid by bromelain derived peptides}

319 Preliminary experiments with proteolytically active 'fruit bromelain' indicated that the enzyme

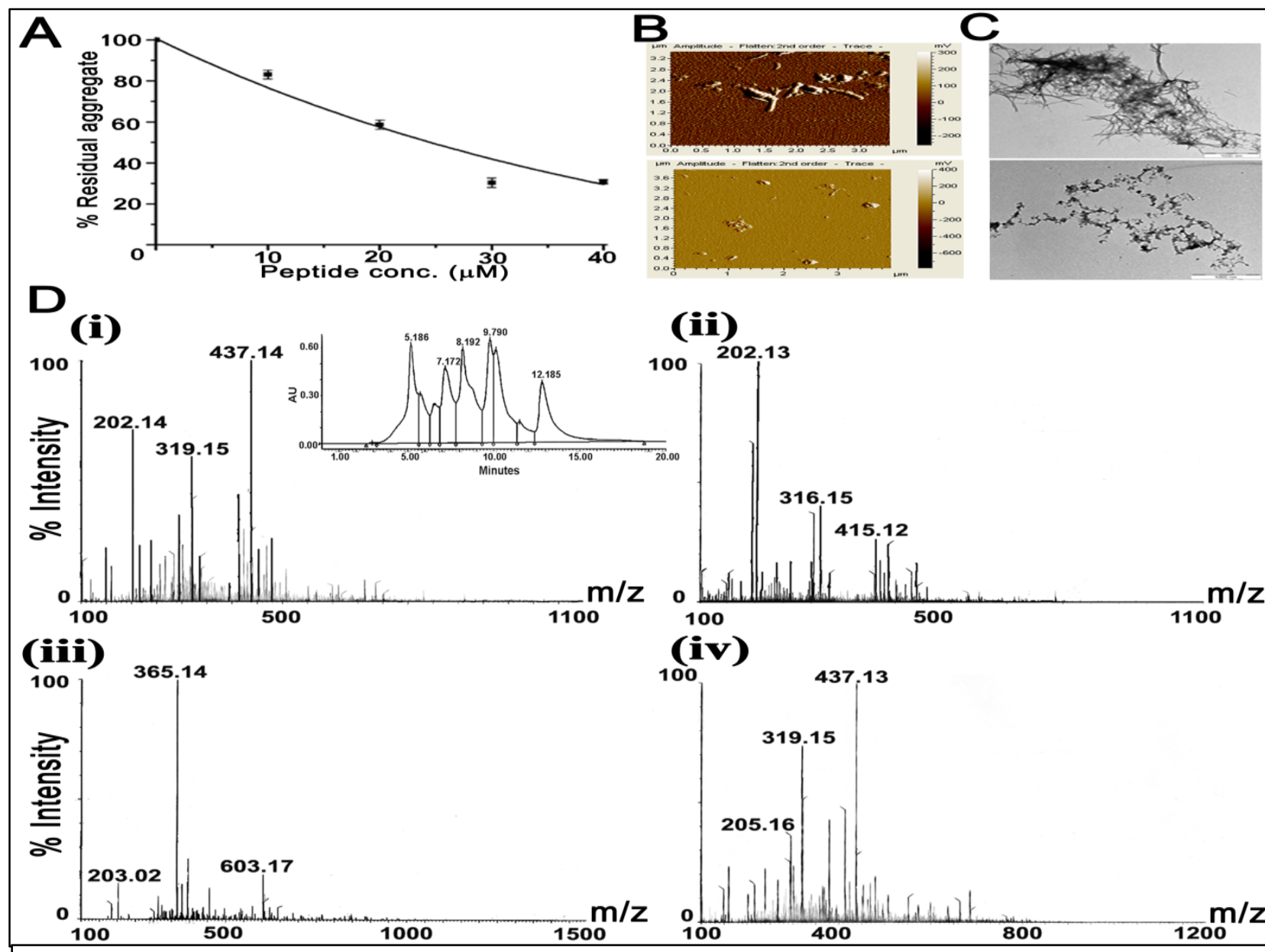

Fig. 1: Destabilization of preformed A $\beta 40$ aggregates and ESI mass analysis of different fractions of peptides. (A) Dependency of destabilization of $A \beta 40$ aggregates on concentration of peptides. Residual structure was measured by Thioflavin-T assay. (B) AFM image of the preformed A $\beta 40$ aggregate of $72 \mathrm{hr}$ (upper panel) and the disaggregated state (lower panel). (C) Corresponding TEM images have been shown in (upper panel) and (lower panel). Experimental conditions have been described in the text. (D) Fruit bromelain was treated with digestive enzymes and the peptide pool was separated using Sephadex G-10 size exclusion column. The peak fractions corresponding to retention times $\left(\mathrm{R}_{\mathrm{t}}\right)$ 5.186, 7.172, 8.192 and 9.790 min were analyzed by ESI-MS (i-iv). Being in the desalting zone, the last chromatographic fraction of $R_{t}=12.185$ min was not analyzed. The HPLC profile has

was capable of destabilizing preformed $A \beta 40 / 42$ fibrillar structures to small oligomers. This was

321 also observed using inactive or proteolytically degraded 'fruit bromelain' or even synthetic 
322 peptides using specific template of 'fruit bromelain' sequence. Therefore the underlying

323 mechanisms might be proteolysis or interaction between amyloid structures and specific amino 324 acid stretches of fruit bromelain or a combination thereof. Mass spectrometric analysis of 325 dissociated products of $A \beta$ amyloid never revealed any fragment smaller than the monomeric $A \beta$ 326 peptide.

The pool of eluted peptides were capable of disaggregating preformed $A \beta 40(10 \mu \mathrm{M})$ in a concentration dependent manner $(0-40 \mu \mathrm{M})$ as suggested from ThT assay. Under experimental conditions, approximately $70 \%$ of disaggregation was achieved after $24 \mathrm{hr}$ of incubation (Fig. 1A). AFM images demonstrated dense fibrillar structure of pretreated $A \beta$ amyloid aggregates (Fig. 1B, upper panel, left) while they followed course of degradation in presence of bromelain peptides (Fig. 1B, lower panel, left). During imaging, the skeleton of fibril though visible, at places the connections were loose. Fibril structure of $\beta$-amyloid aggregate was degraded by peptide pool, compared to matured fibrils of control sample. Corresponding TEM micrographs showed that fibrillar network was composed of rod-like structures of variable length and diameter that were fragmented to small spherical oligomers to monomer like molecules (Fig. 1C, upper and lower panels). As a negative control, it was ensured from both AFM and TEM that the fibrillar structure was stable under conditions of incubation with peptides for $24 \mathrm{hr}$. Encouraged by this observation, peptides of $\mathrm{Mw}<500 \mathrm{Da}$ were isolated from bromelain digest as they may enter into the blood stream, Mw being one of the precondition to cross BBB.

SE-HPLC profile of peptide pool generated from freshly prepared pineapple after human protease digestion (Fig. S-1A) revealed unresolved overlapping broad peak. 15\% SDS-PAGE indicated diffused band around $10 \mathrm{kDa}$ (Fig. S-1B). Corresponding MALDI-MS analysis also deciphered mixture of undigested protein part and digested polypeptides ranging from 10005000 Da (Fig. S-1C). Most of these polypeptides were $>700 \mathrm{Da}$, the molecular mass limit for a substance to cross BBB [25]. The viability of peptide-based aggregation mediator is determined by its ability to cross $\mathrm{BBB}$ and withstand in vivo conditions leading to mediator degradation. Low molecular weights are needed for crossing BBB and the transport must also be done without any degradation of aggregation mediator [26]. 
353 (i) - (iv) Inset). Except one peptide of $\mathrm{Mw}$ 603.17, Mw of all major peptides of these 4 fractions 354 were <500 Da (200- 437 Da) (Fig. 1D). These fractions were pooled as stock solution for subsequent experiments. Fractions eluting ahead of Fraction I with Mw >500 Da were excluded.

Destabilization of A $\beta 40$ aggregate by digested bromelain derived small peptides of $\mathrm{Mw}$ $<500$ Da

358 Th T assay - Disassembly of preformed A $\beta 40$ fibrils by peptide pool was both concentration and 359 time dependent. With increasing peptide concentration from $0-40 \mu \mathrm{M}$ keeping
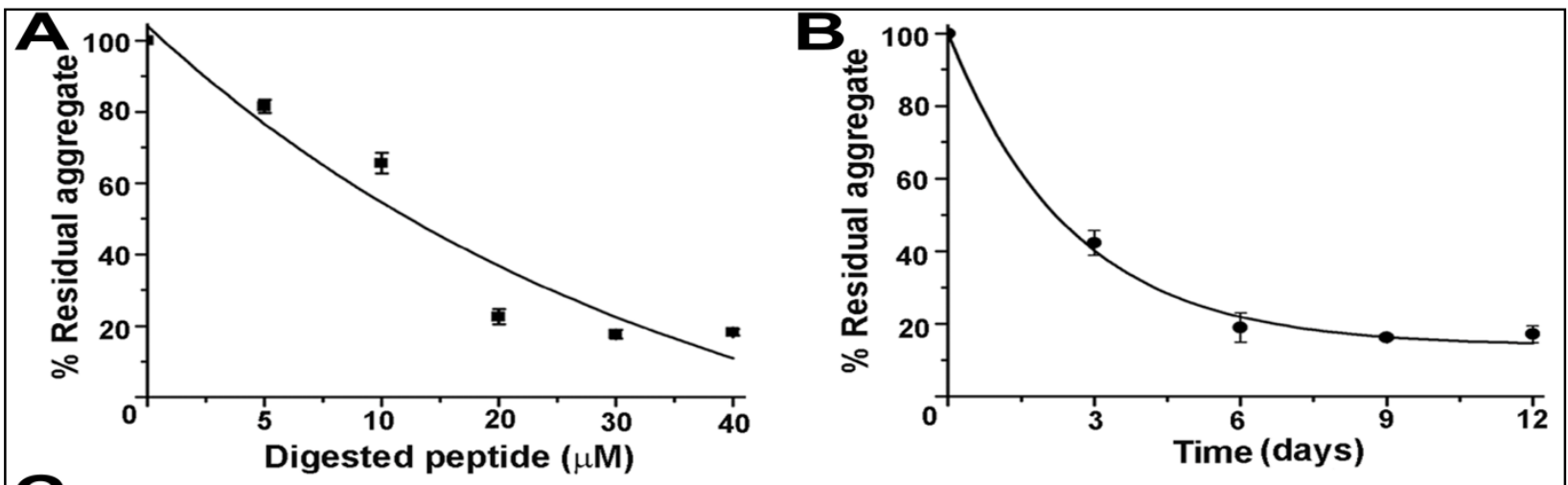
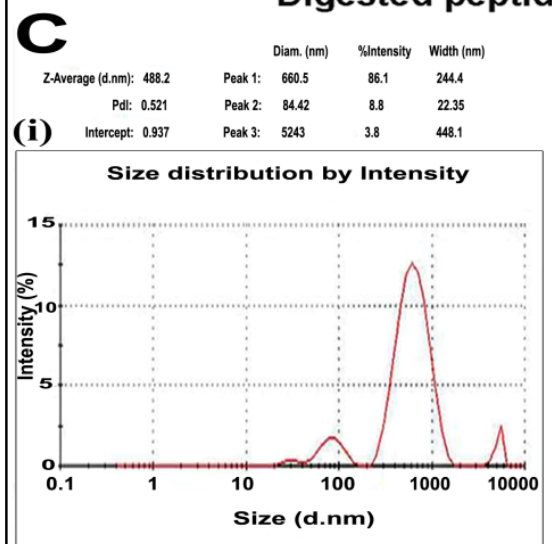

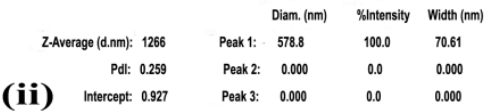

Size distribution by Intensity

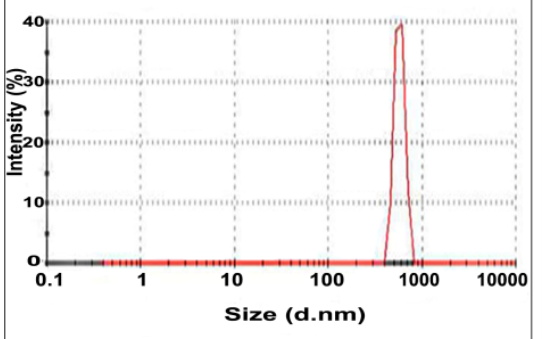

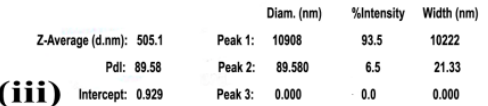

Size distribution by Intensity

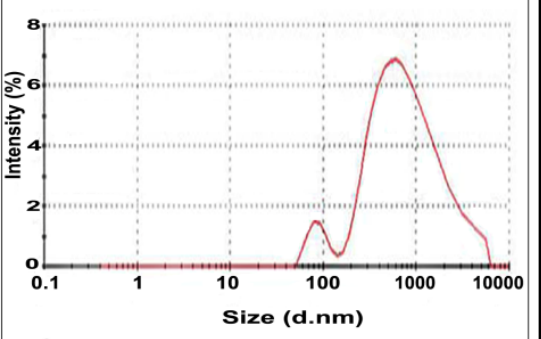

Fig. 2: Destabilization of $A \beta 40$ aggregate and analysis of hydrodynamic radius of different forms

of A $\mathbf{\beta 4 0}$. Dependency of disaggregation on (A) the concentration of pool of digested peptides (1-40 $\mu \mathrm{M}$ ) in $48 \mathrm{hr}$ and (B) time using $7 \mu \mathrm{M}$ of the peptide pool as measured by Th-T fluoremetric analysis. (C) DLS measurements of (i) Monomeric A $\beta 40$, (ii) A $\beta 40$ fibrils and (iii) preformed $A \beta 40$ aggregates after incubation in the presence of fruit bromelain peptides after $48 \mathrm{hr}$ of incubation at $37^{\circ} \mathrm{C}$. duration of incubation and temperature at $24 \mathrm{hr}$ and $37^{\circ} \mathrm{C}$ respectively, aggregates exponentially 363 destabilized having a residual structure of around 20\% (Fig. 2A). Similarly, increasing 364 incubation time from 0-12 days keeping peptide concentration and temperature at $7 \mu \mathrm{M}$ and 
$37^{\circ} \mathrm{C}$ respectively, an exponential time course having $85 \%$ disaggregation was observed (Fig. 2B).

$D L S$ - DLS profiles of monomeric, aggregated and disaggregated states of $\mathrm{A} \beta$ showed actual particle distribution according to size in diameter avoiding stability factors against shearing forces (Fig. 2C). Average diameter of particles present in these sets were $488.2 \mathrm{~nm}, 1266 \mathrm{~nm}$, $509.1 \mathrm{~nm}$ for monomer, aggregate and disaggregate respectively as observed within scale of detection. In case of aggregated state, majority of the particles were out of scale and could not be detected. The correlogram coefficient data of DLS shows the time at which the correlation starts to significantly decay as an indication of mean size of the sample. Further, high monodispersity of a sample is a measure of how steep the line is and conversely, polydispersity of the sample is indicated by how extended the decay takes (figure not shown). These features were in good agreement with DLS profiles (Fig. 2C). Th-T and DLS analysis preliminary indicate A $\beta$ disaggregation potency of peptide pool.

\section{Inhibition of $A \beta 40$ aggregate formation by digested peptide pool}

Digested peptide pool inhibits A $\beta 40$ aggregate formation from monomers - Time course of A $\beta 40$ aggregate formation in presence and absence of bromelain peptides was followed for $96 \mathrm{hr}$. TEM images revealed that even at $0 \mathrm{hr}$, monomeric $A \beta 40$ was contaminated with trace amounts of very small multimeric components. Samples represented in Fig. 3A are electron micrographs reveal clear time dependent aggregation kinetics at 0, 6, 20, 72 and $96 \mathrm{hr}$ time intervals. While oligomerisation was noticed after first $20 \mathrm{hr}$, aggregates were visible roughly around $48 \mathrm{hr}$ onwards. But in the presence of digested peptide, there were no aggregates even up to $96 \mathrm{hr}$ indicating total abolition of aggregation formation. All three phases of $A \beta 40$ aggregation kinetics was monitored through Th-T fluorescence at same time intervals ( 0 - 96 hr) (Fig. 3C) exhibiting a sigmoidal curve showing static fluorescence intensity up to $20 \mathrm{hr}$, indicating lag period represented by presence of monomers and small oligomers. After which, there was an intermediate phase from where larger oligomers and other intermediate forms might have formed till $48 \mathrm{hr}$ followed by the last saturation phase where, fully matured fibrils are formed thereafter, where Th-T fluorescence became static. In presence of digested peptide, this sigmoidal pattern of A $\beta 40$ aggregation kinetics was disturbed, and showed only a lag phase with monomers or small oligomers only. This has been supported by AFM images (Fig. S-2A). 
Digested peptide pool inhibits A 40 aggregate formation from oligomers - Fig. 3D shows Th-T fluorescence data of $A \beta 40$ in the presence and absence of digested peptide pool from the oligomeric stage onwards at 20,36, 48, 72 and $96 \mathrm{hr}$ time intervals. Th-T fluorescence increased from 20 to $96 \mathrm{hr}$ indicating formation of fibrils from oligomers stage on contrast to a significant decrease in the intensity profile in presence of peptides, indicating inhibitory effect on oligomers even after aggregation continued up to $20 \mathrm{hr}$. These results were further confirmed by TEM (Fig. 3B) and AFM images (Fig. S-2B).

Digested peptide pool disaggregated preformed A 40 fibrils - Under defined conditions of selfaggregation, $A \beta 40$ was incubated and aliquots withdrawn for TEM imaging. The sample after 96 $\mathrm{hr}$ of incubation showed an extensive network of branched fibrillar structures having high degree of cross-links. With increase of incubation period up to 7 days, overlapping fibrillar structures became denser and more matured with heavy branching. In either set, no trace of oligomeric components could be detected. (Fig. 3E upper panel). When these samples were separately treated with bromelain peptides for 7 days at $37^{\circ} \mathrm{C}$, dense fibrillar structures completely dissociated into small oligomers and further down to monomer or dimer that remained undetected by TEM. Very small pieces of broken fibrillar structures were visible in the 7 days sample as compared to $96 \mathrm{hr}$ (Fig. 3E lower panel). Samples were also treated with Th-T to estimate presence of aggregated structures. Assuming that the emission intensity of the selfaggregated sample after 7 days was $100 \%$, the $96 \mathrm{hr}$ incubation sample offered nearly $95 \%$ emission suggesting complete aggregation. In either set, disaggregated fibrils offered nearly $20 \%$ of emission intensity. Considering that $A \beta 40$ in its monomeric condition at $0 \mathrm{hr}$ shows nearly $10 \%$ emission, Th-T assay indicates that disaggregation was nearly complete in each set (Fig. $3 \mathrm{~F})$.

\section{Disassembly of pre-formed $A \beta 42$ fibrils by digested bromelain peptides}

The potency of $A \beta 42$ to form amyloid aggregate is higher than $A \beta 40$ and therefore, is clinically more important. Though the 'sticky' hydrophobic regions of the two peptides (15 - 21) are identical, presence of two additional residues at $\mathrm{C}$-terminal end of $\mathrm{A} \beta 42$ renders it more toxic [27]. TEM image of $A \beta 42$ monomers showed presence of trace amount of small oligomers as physical impurity (Fig. 3H(i)). The monomer on self-aggregation for 7 days under defined conditions exhibited dense overlapping fibrillar network with extensive branching where oligomers remained undetected (Fig. 3H(ii)). Preformed A 442 fibrils when treated with 


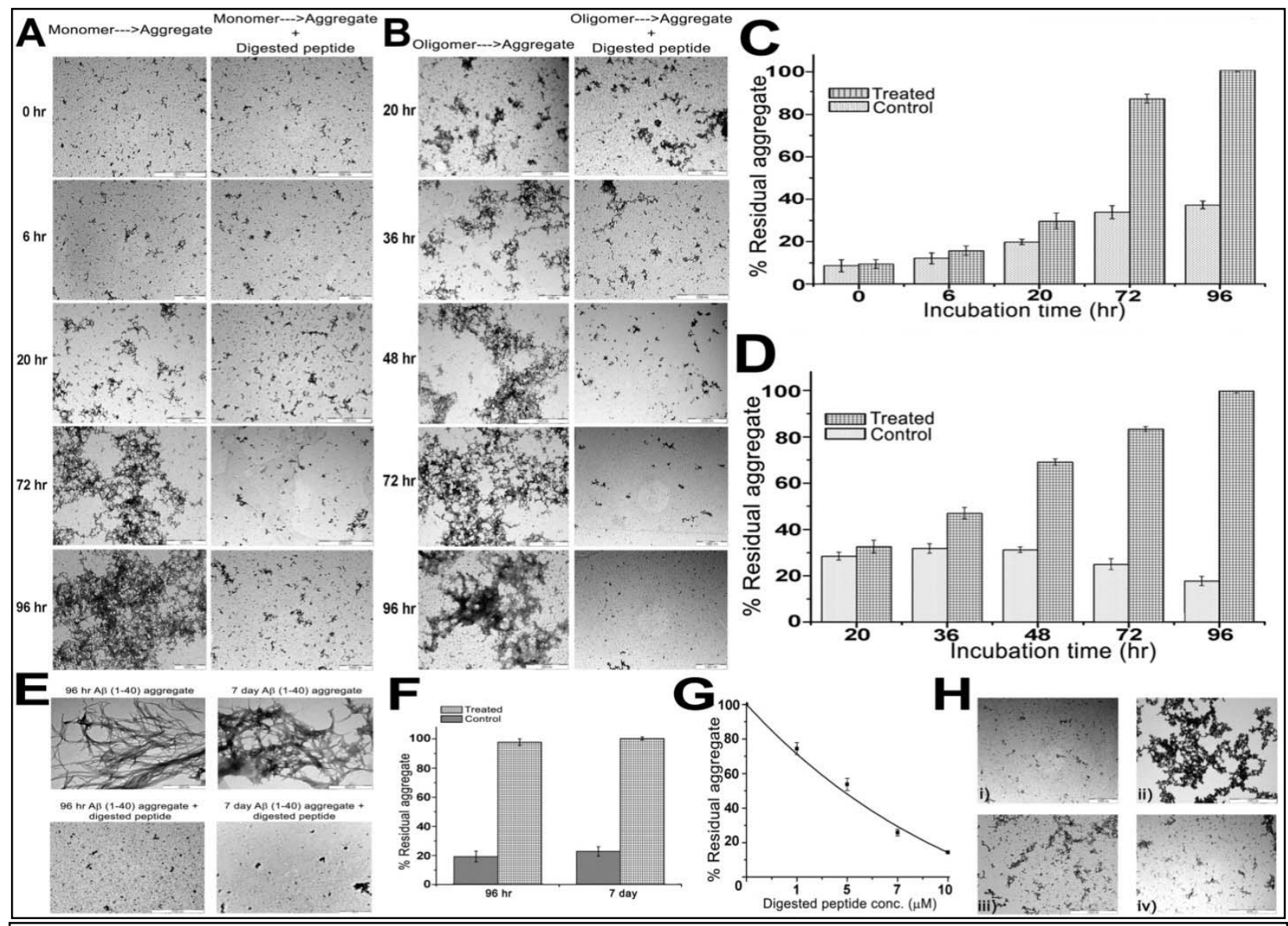

Fig. 3: Aggregation kinetics of A $\mathbf{\beta 4 0 / 4 2}$ fibrils. (A) Monomer to aggregate: $A \beta 40$ was incubated in absence (left panel) and presence (right panel) of $7 \mu \mathrm{M}$ digested peptide at $37^{\circ} \mathrm{C}$. (B) Oligomer to aggregate: Oligomers were generated after incubating A $\beta 40$ for $20 \mathrm{hr}$ under fibrillating conditions were incubated under similar conditions as in A. Aliquots were withdrawn at time intervals as indicated vertically. Corresponding Th graphs of A and B have been depicted in C and D respectively. In both panels, emission intensity of the sets at $96 \mathrm{hr}$ was considered as 100\% (See also Fig. S2). (E) TEM images: (Upper panel) A $\beta 40$ incubated under defined conditions of fibrillation for $96 \mathrm{hr}$ and 7 days. (Lower panel) Corresponding sets after incubation with peptide pool for 7 days. (F) Th $\mathrm{T}$ assay of the four samples presented in $\mathrm{E}$ where absence and presence of the peptides have been denoted as control and treated. Intensity of the control sample after 7 days has been considered as $100 \%$. (G) Estimation of concentration of peptide pool as measured from Th $\mathrm{T}$ assay during disaggregation. Fluorescence from spontaneously formed aggregates after 7 day was considered as 100\%. (H) TEM images of (i) monomeric $\mathrm{A} \beta 42$, (ii) monomeric $\mathrm{A} \beta 42$ fibrillation for $96 \mathrm{hr}$ at $37^{\circ} \mathrm{C}$; (iii) fibrillation as seen in presence of peptide pool for $48 \mathrm{hr}$ and (iv) protease digested peptide pool, inhibiting A $\beta 42$ aggregation. 
days, dissociation of network structure was observed with generation of varied oligomers where links between large oligomers were either nonexistent or very feeble (Fig. 3H(iii)). With passage of time, moderately large oligomers reduced in size and links between them were abolished (Fig. 3H (iv)). Defibrillization was dependent on peptide concentration $(0-10 \mu \mathrm{M})$ holding all other experimental conditions constant as observed from Th-T. Acknowledging limitations of Th-T and interference from monomeric $\mathrm{A} \beta 42$ peptides, it may be stated that bromelain peptides (10 $\mu \mathrm{M})$ can efficiently dissociate preformed $\mathrm{A} \beta 42$ fibrils into small oligomers (Fig. 3G).

\section{Change in secondary and tertiary structures}

To have an insight of the molecular structure of $A \beta 40$ peptides during the course of aggregation and disaggregation, interaction with the fluorophore 8-ANS sensing hydrophobic patches of anchoring proteins, FT-IR and CD spectroscopy were applied. Four states of A $\beta 40$ were characterized; the monomeric state, self-aggregated state where fibrillar structure was formed by 7 days, the same incubate in presence of bromelain peptides where aggregation was inhibited and disaggregated state from preformed fibrils after interaction with bromelain peptides.

Interaction with ANS - Interaction of aforementioned states of A $\beta 40$ with 0 - $300 \mu \mathrm{M}$ ANS was followed. It showed significant and comparable interactions with monomeric, aggregation inhibited and disaggregated states where the interaction with aggregated state was greatly reduced. In all sets, emission intensity reached plateau level between $450-500 \mu \mathrm{M}$ of ANS indicating saturation of ligand binding. Considering emission intensity of disaggregated state as $100 \%$, relative emissions from monomeric, aggregation inhibited and aggregated states were 95.54, 90.27 and $45.99 \%$ respectively (Fig. 4A). This profile also shows that structures of the three sample sets constituting monomer and small oligomers were similar but not identical so far their interactions with ANS was concerned. A simplified explanation for low ANS binding with aggregated state is that hydrophobic stretches of constituent molecules were no more available. To ensure that low affinity of ANS with aggregated state did not arise from an artifact, time course of aggregate formation was followed in presence of $500 \mu \mathrm{M}$ of ANS up to $96 \mathrm{hr}$. Dduring this period, reduction of emission intensity followed an exponential pattern leading to $64 \%$ while considering the emission at $0 \mathrm{hr}$ as $100 \%$. (Fig. 4B). The dissociation constant $\left(\mathrm{K}_{\mathrm{d}}\right)$ of the conjugate has been calculated to be $11.171 \mu \mathrm{M}$. 

$-1600 \mathrm{~cm}^{-1}$. While bands in the range of $1648-1657 \mathrm{~cm}^{-1}$ are assigned for $\alpha$-helix, those between $1623-1641 \mathrm{~cm}^{-1}$ and $1674-1695 \mathrm{~cm}^{-1}$ are assigned for high frequency $\beta$-sheet
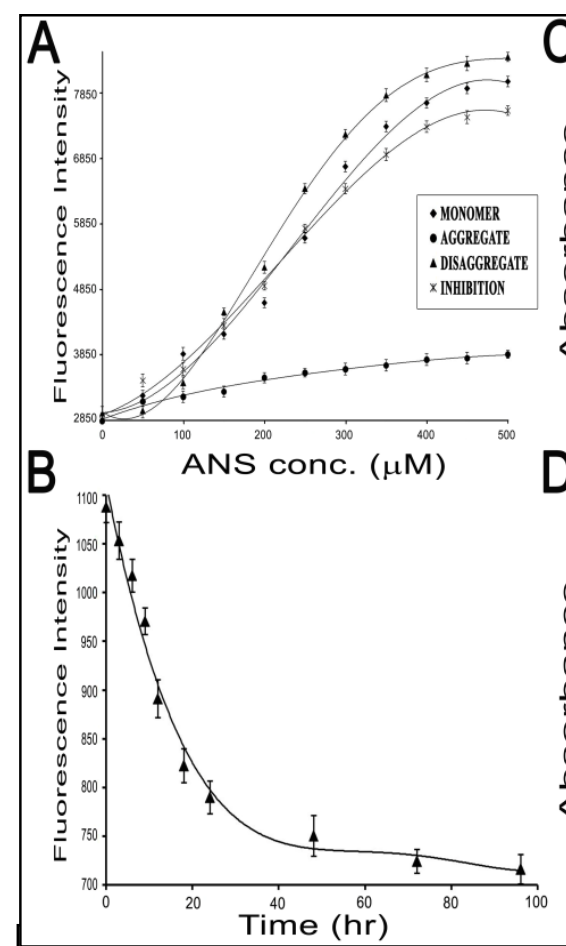
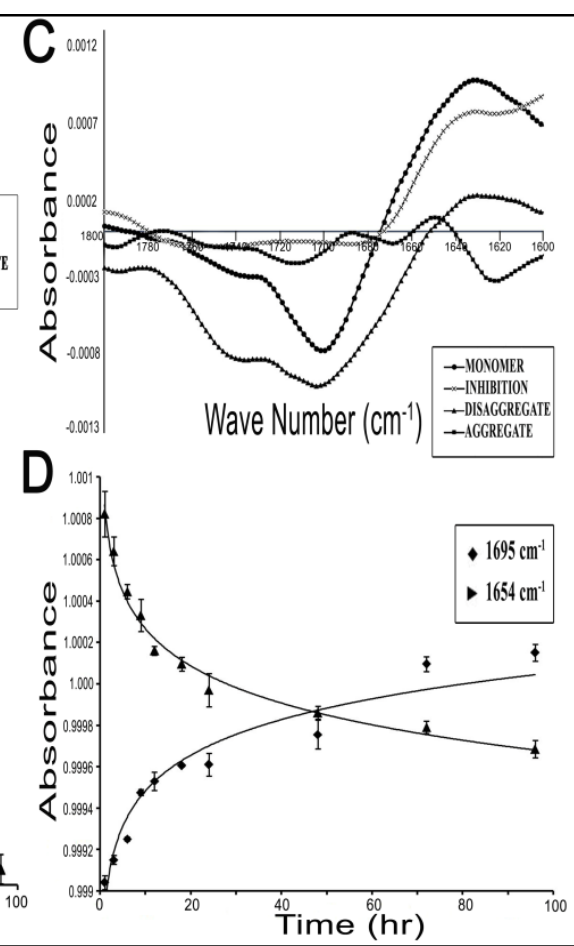

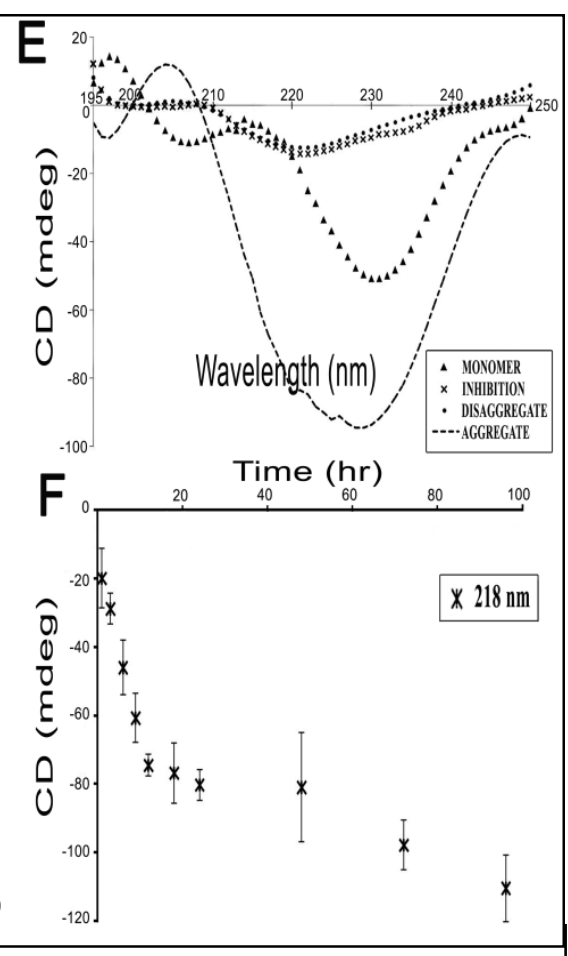

Fig. 4: Spectroscopic analysis of different forms of Aß40. (A) Concentration dependency of ANS interaction as observed from fluorescence emission intensities. (B) Interaction of ANS (500 $\mu \mathrm{M})$ as followed with different species of $A \beta$ during the time course of aggregation. (C) FT-IR spectra ranging from 1800-1600 $\mathrm{cm}^{-1}$ for different species of $\mathrm{A} \beta$. (D) Change of secondary structure of $\mathrm{A} \beta 40$ during fibrilization was followed at $1695 \mathrm{~cm}^{-1}$ and $1654 \mathrm{~cm}^{-1}$. (E) Far UV CD spectra (195-250 nm) of these states and (F) Time course of aggregate formation from monomeric state as observed from ellipticity values at $218 \mathrm{~nm}$. Each spectral value is the average of 5 runs and in all sets, buffer corrections have been done. The descriptions of the notations have been provided in respective insets. All experimental conditions have been mentioned in details in the text.

components. Since rotational-vibrational spectra of proteins are very sensitive to their electronic environment, no single wave number could be assigned to these protein structures [28]. FT-IR spectra of monomeric, aggregated and disaggregated A $\beta 40$ peptide and the inhibited form were scanned in along $1590-1710 \mathrm{~cm}^{-1}$. Significant differences of spectra and therefore structures were predicted (Fig. 4C). While correlating these results with structure, significant loss of residual $\alpha$-helices and gain of $\beta$-sheet structure of monomeric A $\beta 40$ during aggregate formation 
467

468

469

470

471

472

473

474

475

476

477

478

479

480

481

482

483

484

485

486

487

488

489

490

491

492

493

494

495

was observed between $0-96 \mathrm{hr}$ at $1654 \mathrm{~cm}^{-1}$ and $1695 \mathrm{~cm}^{-1}$ respectively [29] (Fig. 4D). FT-IR results though semi-quantitative, characteristic features of protein aggregate formation were evident.

$C D$ - Far-UV CD spectra of aforementioned states between 195 - $250 \mathrm{~nm}$ showed distinct change of secondary structures (Fig. 4E). $\beta$-sheet content of monomeric peptide was calculated to be $24 \%$ that was comparable to $27 \%$ as reported [30]. This minor difference is expected to arise from solvent composition initially used to solubilize the peptide. An increase of negative ellipticity of aggregated state was evident indicating rigidity of structure. The disaggregated state and the peptide resisting aggregation showed similar low ellipticities in the whole spectral range indicating generation of distinctly different conformers and prevalence of random coil structures. To follow formation of aggregated state from monomers through oligomeric states, change of ellipticity was followed for $96 \mathrm{hr}$ at $218 \mathrm{~nm}$. A continuous decrease of negative ellipticity was indicative of $\beta$-sheet formation, a characteristic feature of amyloid-like structures. The decrease appeared to be continuous as fibrillar structures require longer time for maturation (Fig. $4 \mathrm{~F})$. It is noteworthy that the disaggregated state and monomer that inhibits aggregate formation had very similar random coil rich structures.

\section{Sequence alignments of fruit bromelain and A $\beta$ peptide using ClustalW2}

Amino acid sequence of fruit bromelain constituting 351 amino acids (UniProtKB-O23791) and A $\beta 40 / 42$ were aligned using ClustalW2 (multiple sequence alignment) software (Fig. 5A). Previous studies reported ${ }^{16} \mathrm{KLVFFAE}^{22}$ of $\mathrm{A} \beta 40 / 42$ as the most aggregate prone zone of the peptide that forms the core of aggregate from which fibrils propagate [31]. Reports assign tryptophan as a potent residue for $A \beta$ fibrillation and plaque formation [32]. Alignment of sequences of fruit bromelain and $A \beta 40 / 42$ peptides showed significant degree of homology around the aggregate prone zone of $A \beta$ peptide. Alignment of fruit bromelain to Phenylalanine rich sequence KLVFFAE of $A \beta 40$ [Clustal $W$ 2.0] and analyses of peptides generated after gastrointestinal digestion deciphered [Expasy Peptide Cutter] probable bromelain peptides as TIIGY and GQD. In vitro experiments conducted with these peptides indicated specificity of small bromelain peptides in disaggregation as visualized from microscopic images (Fig. 5B) and was hence further used for in-vivo and ex-vivo analyses. 


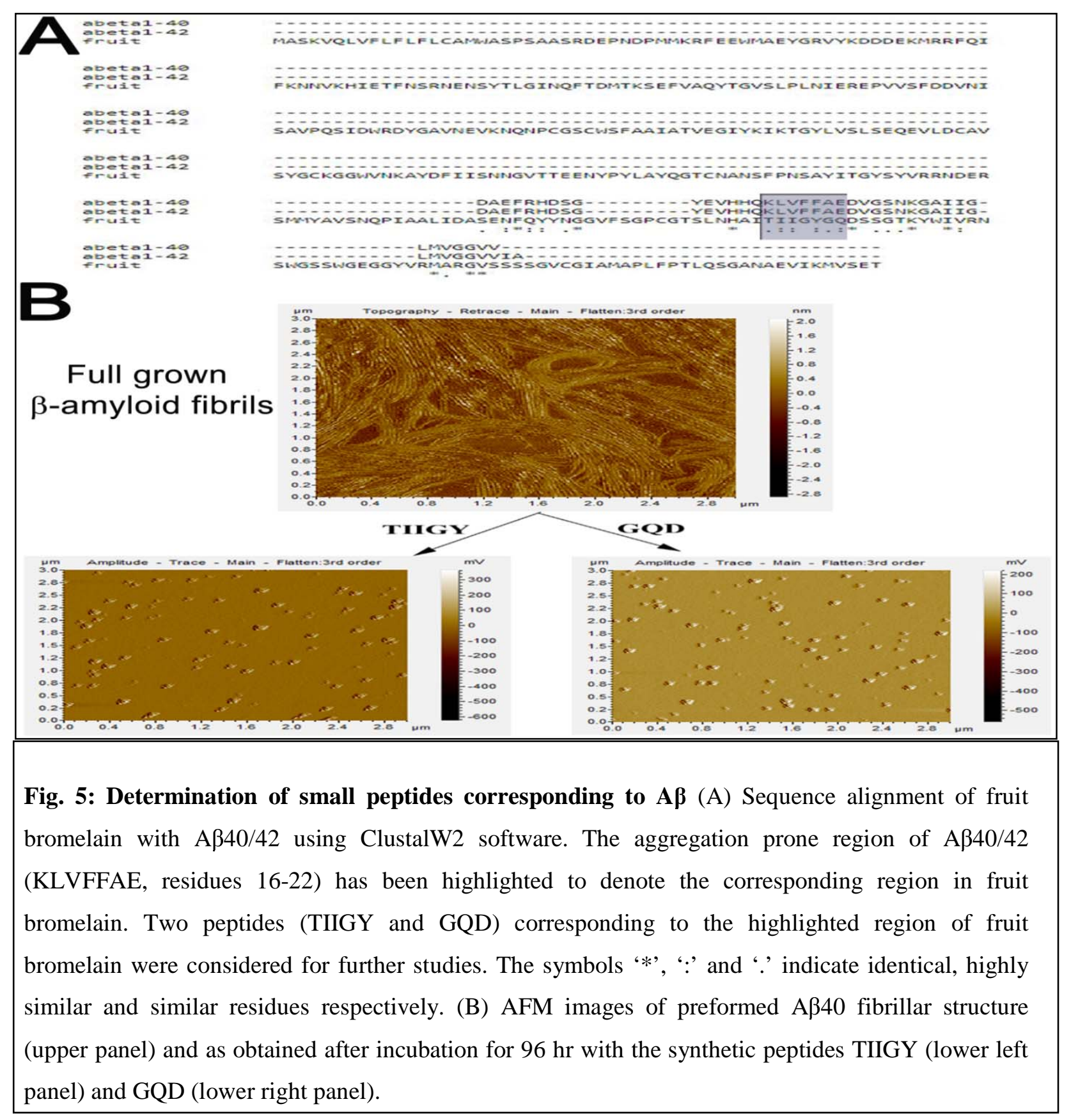

497 Cellular Studies

498 Cell viability assay - Based on positive responses of in vitro experiments, viability of PC12 cells 499 was checked based on dose dependency to optimize $\mathrm{A} \beta$ and bromelain peptide concentrations 500 suited non-toxic to cells. The measured cytotoxicity increased significantly with increasing 501 concentrations of $A \beta 40$ within the range of $20 \mu \mathrm{M}-20 \mathrm{mM}$. An optimum concentration of 7 
$\mathrm{mM}$ was optimized for further experiments. This concentration though higher than physiological conditions was maintained to enhance rate of reaction within experimental timeframe (Fig. 6).

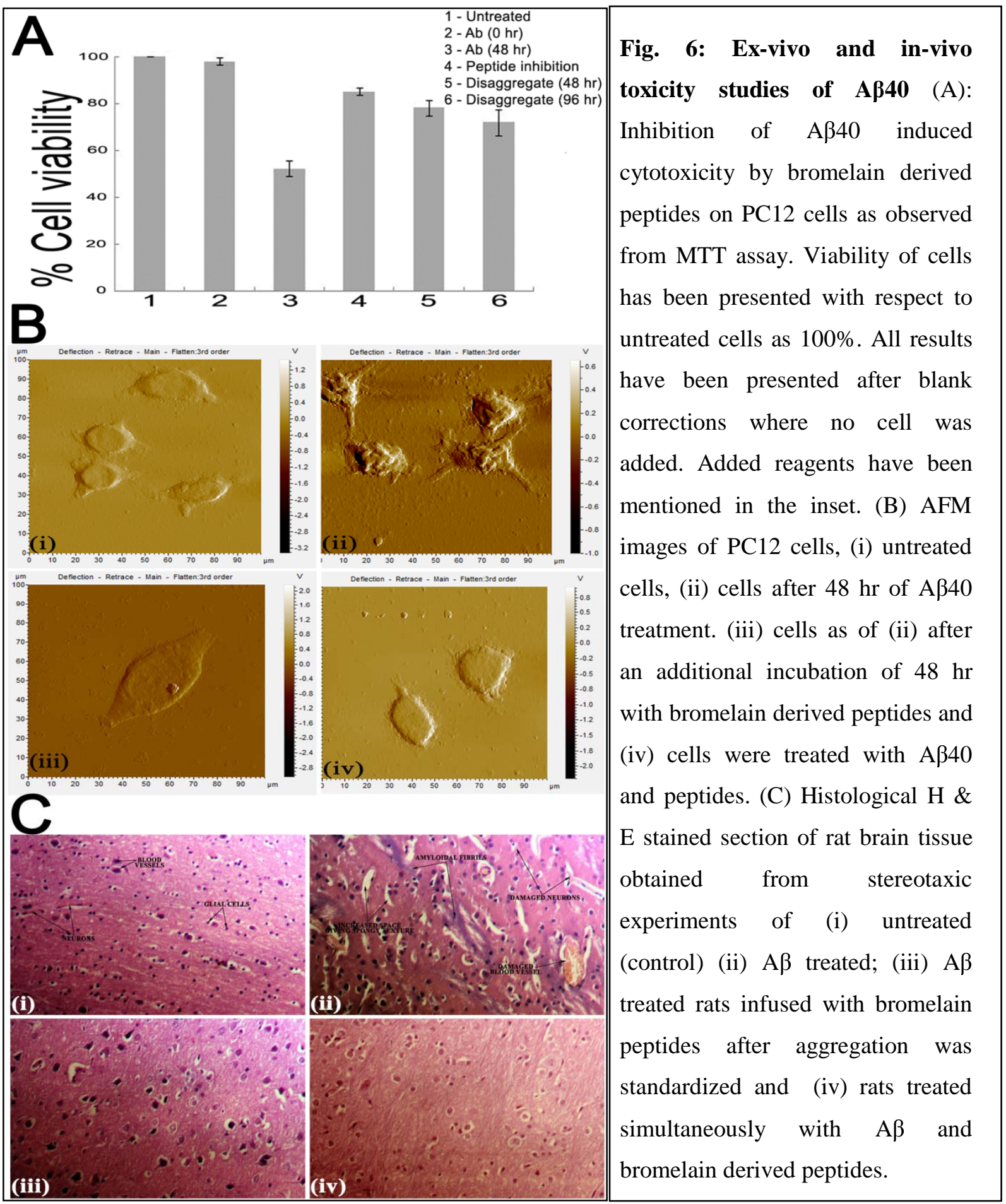

Viability of untreated cells in DMEM medium at 0 and $48 \mathrm{hr}$ of incubation was 
507 after treatment with $\mathrm{A} \beta$ at 0 and $48 \mathrm{hr}$ was $99.01 \pm 1.5 \%$ and $52.23 \pm 3.4 \%$ respectively (Fig. 6A,

508 lanes 1, 2 and 3). Cells when co-incubated with $\mathrm{A} \beta$ and bromelain peptides for $48 \mathrm{hr}$, exhibited 509 viability of $85.04 \pm 1.5 \%$ [lane 4], when treated with peptides following $A \beta$ deposition exhibited $510 \quad 78.21 \pm 3.3 \%$ and $71.91 \pm 5.6 \%$ viability after 48 and $96 \mathrm{hr}$ respectively. On the contrary, cells 511 left for an extended period of 2 - 3 days with $A \beta$ without bromelain peptide treatment gradually 512 lost viability and died. Considering the stress pre-imposed on cells by $\mathrm{A} \beta$ deposition, toxicity 513 exerted thereafter by the peptides was insignificant as cells treated as control with only 514 bromelain peptides showed viability of $98.26 \pm 3.7 \%$. Under identical conditions, viability of 515 cells treated with hydrogen peroxide was $2.16 \pm 1.6 \%$. These results ensured that under 516 conditions of peptide treatment, toxicity was removed and cells propagated (Fig. 6A).

517 Microscopic analysis of aggregation and destabilization on cell surface - PC12 cell topography 518 as visualized by AFM concealed aggregate-like deposits on cell surface upon incubation with 519 preformed $\mathrm{A} \beta 40$ monomers $(10 \mu \mathrm{M}) 72 \mathrm{hr}$ (Fig. 6B(ii)) on contrast to clear surface of naïve 520 untreated cells (Fig. 6B(i)). The cell morphology also showed a distinct change with irregular

521 shape, membrane distortions and loss of dendritic growth compared to control cells exhibiting 522 typical elongated structure with well-defined dendrites. While cells treated with $\mathrm{A} \beta$ and 523 bromelain peptides simultaneously (Fig. 6B(iii)) showed regular shape and dendritic processes, 524 those treated with bromelain peptides after $A \beta$ deposition (Fig. 6B(iv)) was indicative of gradual 525 recovery from stressed conditions illustrating smaller dendritic processes. Therefore, 526 destabilization of preformed fibrils and inhibition of deposition by synthetic peptides was 527 specific.

528 Animal Studies

529 Animals infused with $A \beta$ stereotaxically underwent gradual, significant loss in body weight with 530 time (up to $185-220 \mathrm{~g}$ ), whereas control rats that received only aCSF and those that received an 531 infusion of $A \beta$ along with bromelain together maintained normal gain in body weight (280 - 330 532 g) during the same time. A similar observation was also noticed for rats that received bromelain 533 peptides after 21 days post $\mathrm{A} \beta$ infusion that initially lost weight but with treatment of bromelain 534 peptides over a span of 14 days regained weight to a range of 250 - $300 \mathrm{~g}$, in contrast to those 535 treated with $A \beta$ and bromelain peptides simultaneously that did not show any significant change. 
Noticed behavioral changes included decrease in water and food consumption in rats under

537

538

539

540

541

542

543

544

545

546

547

548

549

550

551

552

553

554

555

556

557

558

559

560

561

562

563

564

565

566 stress conditions of $A \beta$ treatment only. Behavioral changes showing decreased activity and gradual change of body mass were supported with histological images obtained from $\mathrm{H} \& \mathrm{E}$ staining of brain tissues of corresponding rats. Sham-controlled rats and those that received aCSF infusion showed clear cortical region with homogeneously spaced brain lobes (Fig. 6C(i)), while those infused with $A \beta$ exhibited a spongy appearance, brain necrosis, marked presence of plaque formation in cortical areas of brain and also exhibited cerebral lobes that were much more spaced with increased intraventricular area. Some of the nuclei showed a ring appearance (Fig. 6C(ii)). Brain samples of both, rats infused with $\mathrm{A} \beta$ and bromelain peptides simultaneously from day 0 (Fig. 6C(iii)) and $\mathrm{AD}$ infused rats treated with bromelain peptides after 21 days (Fig. 6C(iv)) gave images having an improvement in histopathological changes compared to that of $\mathrm{AD}$ control but similar to control rat brains (Fig. 6C).

\section{DISCUSSION}

In a series of studies, we demonstrated that amyloid aggregates of $A \beta$ peptide and insulin [33] could be destabilized by fruit bromelain peptides. In these sets, synthetic peptides derived using template of proteins was independently capable of destabilizing amyloid aggregates. Specificity of these peptides was evident when similar peptides showed inefficiency in performing the same. A common feature in these combinations is that, presence of intact and functional protein or enzyme was not essential to cause destabilization. Proteolytically degraded enzymes and/or even fragments of intact molecules were also capable of disrupting fibrillar structures. This clearly showed that proteolysis was not involved in the dissociation process. Observations further reinforced that fibrillar structures never produced fragments below the Mw of monomeric $\mathrm{A} \beta$ peptide or insulin [33]. This was confirmed from mass spectrometric analysis.

Success of these in vitro experiments does not qualify these peptides causing defibrilization - no matter whether in a pool or purified or synthetic, to act in brain cortex where A $\beta$ fibrils are formed. Major concern is whether they can cross the BBB [34]. Several criteria of the peptides need to be fulfilled to cross BBB viz., hydrophobicity, low molecular weight, high degree of lipid solubility, charge residues of peptides etc [25] of which Mw is a fundamental criterion. Under physiological conditions, peptides of Mw more than 400 - 600 Da are generally excluded by BBB [35]. Though this stringency is not strictly maintained in case of AD patients where compactness of brain cells is affected allowing relatively bigger molecules to enter, in this 
567 study, peptides of $\mathrm{Mw}<500 \mathrm{Da}$ were separated from undigested and large peptides of fruit 568 bromelain after extensive protease digestion followed by gel filtration and their Mws were verified from MS analysis (Fig. 1D). Based on Clustal W alignment and ExPasy software (Peptide Cutter, using peptides pepsin, trypsin, chymotrypsin, carboxypeptidase and elastase), two peptides TIIGY and GQD were synthesized. Their Mws were 565.67 and 318.29 Da and hydrophobicities were 6.6 and -7.4 respectively [36]. The hydrophilic peptide was included because of its uncertainty of functioning with respect to BBB under diseased conditions. These peptides not only destabilized A $\beta$ fibrils in vitro but also protected PC12 cells against death from assault of $\mathrm{A} \beta$ sedimentation (Fig. 6A). These in vitro and ex-vivo information were essential to initiate animal model experiments (Fig 6B \& 6C).

Since pineapple is a widely consumed fruit, efficacy of peptides produced from fruit bromelain after human digestive conditions were verified in rat model. This is strong evidence that if peptides get access to $A \beta$ fibrils in brain, probably they could dissociate the deposits. In this regard, an experiment demonstrating passage of these peptides through artificial brain cell barrier is welcome. Such experiments are performed with synthetic peptides tagged with a small amount of a positron-emitting radioactive atom so that Mw of peptide is not affected and the $\gamma$ radiation is then measured as a function of tissue depth. Computer software is employed to create a three-dimensional image of the distribution of the substance in brain and other tissues [37]. only irreversibly dissociates preformed $A \beta$ fibrils (Fig. 3), but also inhibits formation of $A \beta$ fibrils from monomeric and oligomeric states. This can be achieved in two ways; first, bromelain peptides may bind with monomeric $\mathrm{A} \beta$ peptide presumably protecting the hydrophobic site/s of interaction leading to prevention of aggregation or second, upon binding with bromelain peptides, $A \beta$ peptide undergoes an irreversible conformation change whereby potency of selfassociation is lost. It is now well established that the following equilibration exists during the process or even after fibril formation [38]:

$$
\text { Monomer } \leftrightharpoons \text { oligomer } \leftrightharpoons \text { protofibrillar state } \leftrightharpoons \text { fibrillar structure }
$$

There are evidences from immunological studies using antibodies specific to monomeric or oligomeric $\mathrm{A} \beta$ peptides that even after fibril formation, monomers and oligomers do exist in 596 equilibrium [39]. Certainly the equilibrium shifts to the right (towards fibril formation) when 597 stable fibrillar structures are formed while remains in the middle during onset of aggregation. 
598

599

600

601

602

603

604

605

606

607

608

609

610

611

612

613

614

615

616

617

618

619

620

621

622

623

624

625

626

627

628

Fibrillar structures being very stable, it is difficult to conceive that bromelain peptides directly interact with them and make them unstable. On the other hand, bromelain peptides irreversibly inhibit formation of fibrillar structures from monomeric $A \beta$ peptide indicating positive interaction leading to conformation change. This is demonstrated indirectly from interaction with the fluorophore ANS (Fig. 4A-4B) and directly from CD and FT-IR spectra (Fig. 4C-4F).

An intriguing part of these studies is that often requirement of inhibitor peptides is substoichiometric with respect to $A \beta$ peptides. Though it is not possible to predict molecularity of an aggregate or a mixture of oligomers or peptides in a pool, concentrations of $A \beta$ monomer and synthetic peptides could be accurately determined. From this information, it can be predicted that formation of a stable [A $\beta$ monomer-synthetic peptide] binary complex of 1:1 stoichiometry leading to inhibition of aggregate formation is not possible. The event most pertinent to this situation is synthetic or bromelain derived peptides bind with $A \beta$ monomer causing irreversible conformation change. As a result, after dissociation of the binary complex, $A \beta$ peptides permanently lose their ability to form oligomers and fibrillar structures. The inhibitor peptide in its free state after dissociation from the complex recycles the reaction. This is similar to enzyme turnover.

A large number of medicinal properties have been attributed to fruit 'bromelain'-the fresh fruit extract of pineapple. Though cysteine protease bromelain is the major constituent of the extract, other accompanying components are peroxidases, acid phosphatases, glycosidases, ribonucleases, cellulases, glycoproteins, carbohydrates, protease inhibitors together with organic and inorganic compounds. It is believed that a wide array of medicinal properties reside in this battery of enzymes [14]. Pineapple is a seasonal crop. The fruit is consumed more as a processed product rather than in its raw form. We have reported earlier that due to harsh sterilization conditions, these products are completely devoid of enzymatic activities as the enzymes are either thermally denatured or proteolytically degraded [11]. Since peptides formed after extensive degradation of 'bromelain' enzymes can destabilize fibrillar structures as reported in this study, processed pineapple should be capable of performing similar functions. The statement of Greek physician and philosopher, Hippocrates, 'let food be thy medicine and medicine be thy food', appears meaningful. 
629

630

631

632

633

634

635

636

637

638

639

640

641

642

643

644

645

646

647

648

649

650

651

652

653

654

\section{CONCLUSION}

Peptides generated from fruit bromelain under human digestive conditions can inhibit aggregate formation from monomeric state of amyloidogenic peptides $A \beta 40 / 42$ besides facilitating destabilisation of preformed amyloid fibrils in vitro. Ex vivo studies using PC12 neuronal cells and in vivo studies using animal models suggested reversal of neurotoxicity caused by amyloid peptides in presence of bromelain derived peptides. Probable underlying mechanism has been proposed. Since pineapple is edible, one can initiate clinical trials to determine preventive effects of neuronal toxicities in $\mathrm{AD}$ patients, elderly individuals and in subjects with mild cognitive impairment using fruit peptides.

\section{ACKNOWLEDGEMENTS}

This research was partially supported by CSIR Network Project (mIND BSC 0115). Das S. was supported from the same source. Dutta S was funded by UGC-SRF and RKP was supported by CSIR. We thank Dr. Krishnananda Chattopadhyay and Dr. Sandhya Rekha Dungdung of CSIRIICB for providing their DLS and cell culture facility respectively. Special thanks to Mr. T.Muruganandan, Mr. Sailen De, Mr. Jishu Mondal, Mr. Satyabrata Samaddar, Mr, Sandip Chakraborty and Mr. Diptendu Bhattacharya are due for their technical support in AFM, TEM, CD, FT-IR, MALDI and ESI-MS facilities respectively.

\section{AUTHOR CONTRIBUTIONS}

Conceptualization, S.Das, S.Dutta, R.K.P, S.C.B, U.C.H. and D.B.; Investigation, S.Das, S.Dutta. and R.K.P; Data Analysis, S.Das, S.Dutta. and R.K.P,; Writing, S.Das., S. Dutta. and D.B.; Funding Acquisition, Resources, and Supervision, S.C.B., U.C.H and D.B.

\section{DECLARATION OF INTERESTS}

The authors declare that there is no conflict of interest among themselves.

\section{DATA SHARING AND DATA ACCESSIBILITY}

The data that support the findings of this study are available from the corresponding author upon reasonable request. 


\section{REFERENCES}

657 [1] F. M. LaFerla, K. N. Green, S. Oddo, Nat Rev Neurosci 2007, 8, 499-509.

658 [2] J. Hardy, Science 2002, 297, 353-356.

659 [3] F. Esch, P. Keim, E. Beattie, R. Blacher, A. Culwell, T. Oltersdorf, D. McClure, P. Ward, 660 Science 1990, 248, 1122-1124.

661 [4] C. Haass, M. G. Schlossmacher, A. Y. Hung, C. Vigo-Pelfrey, A. Mellon, B. L. 662 Ostaszewski, I. Lieberburg, E. H. Koo, D. Schenk, D. B. Teplow, et al., Nature 1992, 359, 663 322-325.

664 [5] B. Caughey, P. T. Lansbury, Annu. Rev. Neurosci. 2003, 26, 267-298.

665 [6] D. M. Walsh, I. Klyubin, J. V. Fadeeva, W. K. Cullen, R. Anwyl, M. S. Wolfe, M. J. 666 Rowan, D. J. Selkoe, Nature 2002, 416, 535-539.

667 [7] P. N. Lacor, Journal of Neuroscience 2004, 24, 10191-10200.

668 [8] O. van de Rest, A. A. Berendsen, A. Haveman-Nies, L. C. de Groot, Advances in Nutrition $6692015,6,154-168$.

670 [9] R. Venkatesan, E. Ji, S. Y. Kim, BioMed Research International 2015, 2015, 1-22.

671 [10] H. R. Maurer, CMLS, Cell. Mol. Life Sci. 2001, 58, 1234-1245.

672 [11] S. Das, D. Bhattacharyya, in In Tropical Fruits: From Cultivation to Consumption and 673 Health Benefits, Pineapple (Eds.: C.S. Bogsan, S.D. Todorov), Nova Science Publishers, New 674 York, 2017, pp. 43-100.

675 [12] S. Barghorn, V. Nimmrich, A. Striebinger, C. Krantz, P. Keller, B. Janson, M. Bahr, M. 676 Schmidt, R. S. Bitner, J. Harlan, et al., J Neurochem 2005, 95, 834-847.

677 [13] G. Sarath, R. Motte, F. Wagner, in Proteolytic Enzymes: A Practical Approach (Eds.: R.J. 678 Beynon, J.S. Bond), IRL Press At Oxford University Press, Oxford $\square$; New York, 1996, pp. $67925-55$.

680 [14] T. Murachi, in Methods in Enzymology, Elsevier, 1976, pp. 475-485.

681 [15] B. López-García, M. Hernández, B. S. Segundo, Letters in Applied Microbiology 2012, $68255,62-67$.

683 [16] P. Muñoz-Ruiz, L. Rubio, E. García-Palomero, I. Dorronsoro, M. del Monte-Millán, R. 684 Valenzuela, P. Usán, C. de Austria, M. Bartolini, V. Andrisano, et al., J. Med. Chem. 2005, 48, $6857223-7233$. 
[17] B. J. H. Kuipers, H. Gruppen, J. Agric. Food Chem. 2007, 55, 5445-5451.

687 [18] M. R. Nichols, M. A. Moss, D. K. Reed, W.-L. Lin, R. Mukhopadhyay, J. H. Hoh, T. L. 688 Rosenberry, Biochemistry 2002, 41, 6115-6127.

689 [19] H. B. Bohidar, Colloid \& Polymer Sci 1989, 267, 292-300.

690 [20] F. Yang, G. P. Lim, A. N. Begum, O. J. Ubeda, M. R. Simmons, S. S. Ambegaokar, P. P. 691 Chen, R. Kayed, C. G. Glabe, S. A. Frautschy, et al., J. Biol. Chem. 2005, 280, 5892-5901.

692 [21] S. F. Santos, D. Zanette, H. Fischer, R. Itri, Journal of Colloid and Interface Science 2003, $693262,400-408$.

694 [22] M. Manczak, P. Mao, M. J. Calkins, A. Cornea, A. P. Reddy, M. P. Murphy, H. H. Szeto, 695 B. Park, P. H. Reddy, JAD 2010, 20, S609-S631.

696 [23] R. Paidi, D. Nthenge-Ngumbau, R. Singh, T. Kankanala, H. Mehta, K. Mohanakumar, 697 CAR 2015, 12, 785-795.

698 [24] G. Paxinis, C. Watson, 1998.

699 [25] W. A. Banks, BMC Neurol 2009, 9, S3.

700 [26] J. F. Poduslo, G. L. Curran, A. Kumar, B. Frangione, C. Soto, J. Neurobiol. 1999, 39, $701 \quad 371-382$.

702 [27] N. G. Sgourakis, Y. Yan, S. A. McCallum, C. Wang, A. E. Garcia, Journal of Molecular 703 Biology 2007, 368, 1448-1457.

704 [28] S. Li, X. Su, W. Chen, L. Xiang, J. Opt. Soc. Am. A 2009, 26, 1195.

705

[29] S. Sukumaran, J Mol Biol 2017, 368, 1448-1457.

706 [30] A. K. Paravastu, R. D. Leapman, W.-M. Yau, R. Tycko, Proceedings of the National 707 Academy of Sciences 2008, 105, 18349-18354.

708 [31] I. W. Hamley, Chem. Rev. 2012, 112, 5147-5192.

709 [32] R. Scherzer-Attali, R. Pellarin, M. Convertino, A. Frydman-Marom, N. Egoz-Matia, S. 710 Peled, M. Levy-Sakin, D. E. Shalev, A. Caflisch, E. Gazit, et al., PLoS ONE 2010, 5, e11101.

711 [33] S. Das, D. Bhattacharyya, J. Cell. Biochem. 2017, 118, 4881-4896.

712 [34] A. D. Wong, M. Ye, A. F. Levy, J. D. Rothstein, D. E. Bergles, P. C. Searson, Front. 713 Neuroeng. 2013, 6, DOI 10.3389/fneng.2013.00007. 
714 [35] C. A. Lipinski, F. Lombardo, B. W. Dominy, P. J. Feeney, Advanced Drug Delivery

715 Reviews 2001, 46, 3-26.

716 [36] J. Kyte, R. F. Doolittle, Journal of Molecular Biology 1982, 157, 105-132.

717 [37] C. D. Kuhnline Sloan, P. Nandi, T. H. Linz, J. V. Aldrich, K. L. Audus, S. M. Lunte, 718 Annual Rev. Anal. Chem. 2012, 5, 505-531.

719 [38] S. Nag, B. Sarkar, A. Bandyopadhyay, B. Sahoo, V. K. A. Sreenivasan, M. Kombrabail, 720 C. Muralidharan, S. Maiti, J. Biol. Chem. 2011, 286, 13827-13833.

721 [39] L. Hong, C. F. Lee, Y. J. Huang, in World Scientific Lecture and Course Notes in 722 Chemistry, World Scientific, 2017, pp. 113-186.

723

FIGURE LEGENDS

\section{FIGURE LEGENDS}

726 Fig. 1: Destabilization of preformed A $\beta 40$ aggregates and ESI mass analysis of different

727 fractions of peptides. (A) Dependency of destabilization of $A \beta 40$ aggregates on concentration 728 of peptides. Residual structure was measured by Thioflavin-T assay. (B) AFM image of the 729 preformed $A \beta 40$ aggregate of $72 \mathrm{hr}$ (upper panel) and the disaggregated state (lower panel). 730 (C) Corresponding TEM images have been shown in (upper panel) and (lower panel). 731 Experimental conditions have been described in the text. (D) Fruit bromelain was treated with 732 digestive enzymes and the peptide pool was separated using Sephadex G-10 size exclusion 733 column. The peak fractions corresponding to retention times $\left(\mathrm{R}_{\mathrm{t}}\right)$ 5.186, 7.172, 8.192 and 9.790 734 min were analyzed by ESI-MS (i-iv). Being in the desalting zone, the last chromatographic 735 fraction of $\mathrm{R}_{\mathrm{t}}=12.185$ min was not analyzed. The HPLC profile has been shown in Inset 736 (D(i)). See also Fig. S1.

737 Fig. 2: Destabilization of A $\beta 40$ aggregate and analysis of hydrodynamic radius of different 738 forms of Aß40. Dependency of disaggregation on (A) the concentration of pool of digested 739 peptides $(1-40 \mu \mathrm{M})$ in $48 \mathrm{hr}$ and (B) time using $7 \mu \mathrm{M}$ of the peptide pool as measured by Th-T 740 fluoremetric analysis. (C) DLS measurements of (i) Monomeric A $\beta 40$, (ii) A $\beta 40$ fibrils and (iii) 741 preformed $A \beta 40$ aggregates after incubation in the presence of fruit bromelain peptides after 48 $742 \mathrm{hr}$ of incubation at $37^{\circ} \mathrm{C}$. 
Fig. 3: Aggregation kinetics of $\mathbf{A} \boldsymbol{\beta 4 0 / 4 2}$ fibrils. (A) Monomer to aggregate: A $\beta 40$ was incubated in absence (left panel) and presence (right panel) of $7 \mu \mathrm{M}$ digested peptide at $37^{\circ} \mathrm{C}$. (B) Oligomer to aggregate: Oligomers were generated after incubating A $\beta 40$ for $20 \mathrm{hr}$ under fibrillating conditions were incubated under similar conditions as in A. Aliquots were withdrawn at time intervals as indicated vertically. Corresponding Th graphs of A and B have been depicted in $\mathrm{C}$ and $\mathrm{D}$ respectively. In both panels, emission intensity of the sets at $96 \mathrm{hr}$ was considered as 100\% (See also Fig. S2). (E) TEM images: (Upper panel) A $\beta 40$ incubated under defined conditions of fibrillation for $96 \mathrm{hr}$ and 7 days. (Lower panel) Corresponding sets after incubation with peptide pool for 7 days. (F) Th T assay of the four samples presented in $\mathrm{E}$ where absence and presence of the peptides have been denoted as control and treated. Intensity of the control sample after 7 days has been considered as 100\%. (G) Estimation of concentration of peptide pool as measured from Th $\mathrm{T}$ assay during disaggregation. Fluorescence from spontaneously formed aggregates after 7 day was considered as 100\%. (H) TEM images of (i) monomeric $\mathrm{A} \beta 42$, (ii) monomeric $\mathrm{A} \beta 42$ fibrillation for $96 \mathrm{hr}$ at $37^{\circ} \mathrm{C}$; (iii) fibrillation as seen in presence of peptide pool for $48 \mathrm{hr}$ and (iv) protease digested peptide pool, inhibiting A $\beta 42$ aggregation.

Fig. 4: Spectroscopic analysis of different forms of Aß40. (A) Concentration dependency of ANS interaction as observed from fluorescence emission intensities. (B) Interaction of ANS (500 $\mu \mathrm{M})$ as followed with different species of $A \beta$ during the time course of aggregation. (C) FT-IR spectra ranging from $1800-1600 \mathrm{~cm}^{-1}$ for different species of $\mathrm{A} \beta$. (D) Change of secondary structure of $A \beta 40$ during fibrilization was followed at $1695 \mathrm{~cm}^{-1}$ and $1654 \mathrm{~cm}^{-1}$. (E) Far UV CD spectra (195-250 nm) of these states and (F) Time course of aggregate formation from monomeric state as observed from ellipticity values at $218 \mathrm{~nm}$. Each spectral value is the average of 5 runs and in all sets, buffer corrections have been done. The descriptions of the notations have been provided in respective insets. All experimental conditions have been mentioned in details in the text.

Fig. 5: Determination of small peptides corresponding to $\mathbf{A} \boldsymbol{\beta}$ (A) Sequence alignment of fruit bromelain with $A \beta 40 / 42$ using ClustalW2 software. The aggregation prone region of A $\beta 40 / 42$ (KLVFFAE, residues 16-22) has been highlighted to denote the corresponding region in fruit bromelain. Two peptides (TIIGY and GQD) corresponding to the highlighted region of fruit bromelain were considered for further studies. The symbols '*', ' $’$ and '.' indicate 
773 identical, highly similar and similar residues respectively. (B) AFM images of preformed A $\beta 40$

774 fibrillar structure (upper panel) and as obtained after incubation for $96 \mathrm{hr}$ with the synthetic peptides TIIGY (lower left panel) and GQD (lower right panel).

776

777

778

779

780

781

782

783

784

785

786

Fig. 6: Ex-vivo and in-vivo toxicity studies of $\mathbf{A} \boldsymbol{\beta} 40$ (A): Inhibition of $\mathrm{A} \beta 40$ induced cytotoxicity by bromelain derived peptides on PC12 cells as observed from MTT assay. Viability of cells has been presented with respect to untreated cells as $100 \%$. All results have been presented after blank corrections where no cell was added. Added reagents have been mentioned in the inset. (B) AFM images of PC12 cells, (i) untreated cells, (ii) cells after $48 \mathrm{hr}$ of $\mathrm{A} \beta 40$ treatment. (iii) cells as of (ii) after an additional incubation of $48 \mathrm{hr}$ with bromelain derived peptides and (iv) cells were treated with $A \beta 40$ and peptides. (C) Histological H \& E stained section of rat brain tissue obtained from stereotaxic experiments of (i) untreated (control) (ii) $\mathrm{A} \beta$ treated; (iii) $\mathrm{A} \beta$ treated rats infused with bromelain peptides after aggregation was standardized and (iv) rats treated simultaneously with $\mathrm{A} \beta$ and bromelain derived peptides.

\section{SUPPLEMENTAL INFORMATION}

\section{Supplemental Figures}



Fig. S1: Purification and mass analysis of bromelain peptide pool. (A) SE-HPLC of fruit bromelain derived peptide pool using a Waters Protein Pak 60 column equilibrated with $10 \mathrm{mM}$ Na-P buffer (pH 7.5). Flow rate was $0.8 \mathrm{ml} / \mathrm{min}$ and elution was followed at $220 \mathrm{~nm}$. Retention times of major peaks have been indicated. (B) $15 \%$ SDS-PAGE profiles. Lane 1, Protein markers; Lane 2, Peptide pool marked by bar in the chromatogram. (C) MALDI-MS spectrum of SE-HPLC eluted pool of the peptides. Related to Fig. 2. 


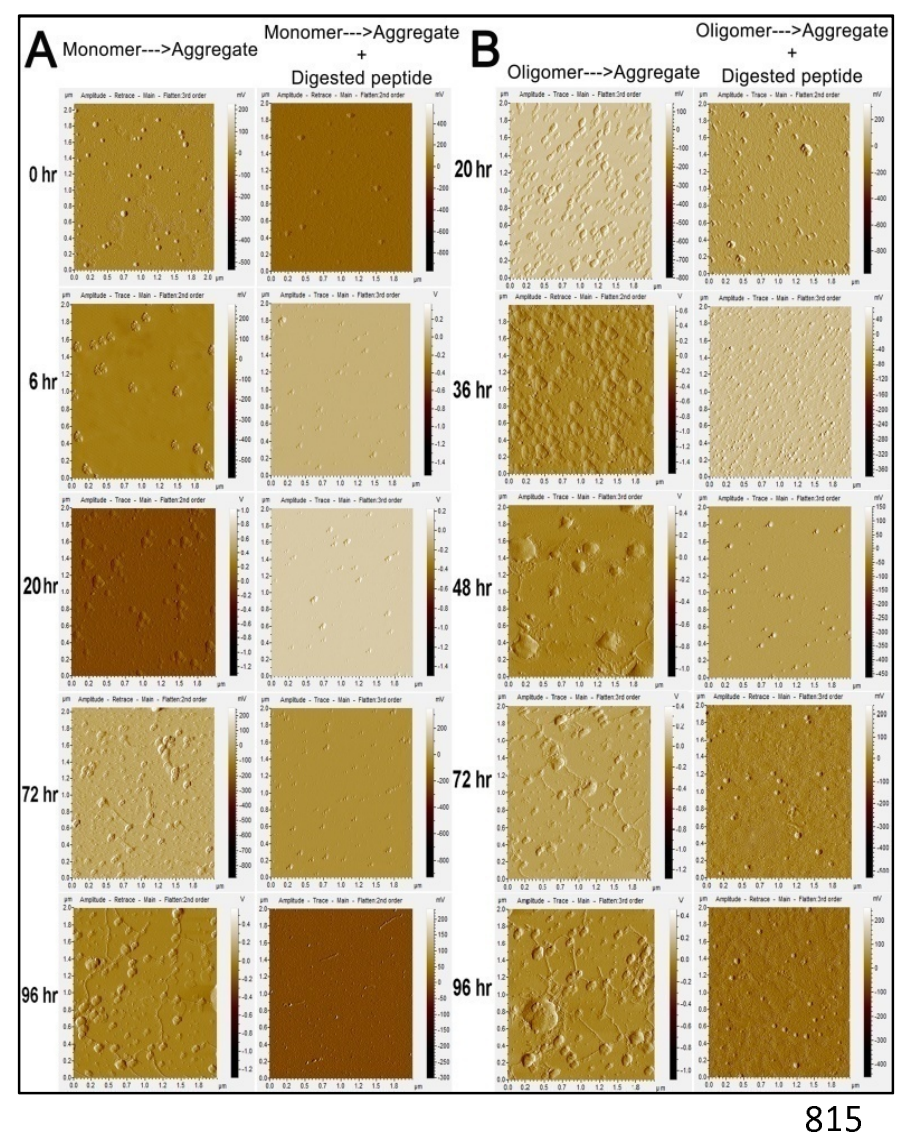

Fig. S2: Time course of aggregation as followed by AFM micrographs. (A) (Monomers to aggregates): A $\beta$ (1 - 40) coincubated in the absence or presence of $7 \mu \mathrm{M}$ of digested peptide at $37{ }^{\circ} \mathrm{C}$ in Na-phosphate buffer (pH 7.5). The aliquots were taken at $0,12,24,72$ and $96 \mathrm{hr}$ and analyzed for the presence or absence of aggregates (B) oligomers to aggregates: $A \beta 40$ was incubated for $20 \mathrm{hr}$ under fibrillating conditions and digested peptide was added after $20 \mathrm{hrs}$ of incubation. Aliquots were taken at 20,36, 48, 72 and $96 \mathrm{hr}$ for analysis of the presence or absence of aggregate. Related to Fig. 3. 